\title{
Nitrogenous Nutrition Affects Uptake of Arsenic and Defense Enzyme Responses in Wheat
}

\author{
Marína Maglovski', L’ubomír Rybanský², Marek Bujdoš ${ }^{3}$ Lubomír Adamec ${ }^{4}$, \\ Monika Bardáčová5*, Alžbeta Blehová6, Ildikó Matušíková5 \\ ${ }^{1}$ Institute of Plant Genetics and Biotechnology, Plant Science and Biodiversity Center SAS, Akademická 2, \\ P.O.Box 39A, 95007 Nitra, Slovakia \\ ${ }^{2}$ Constantine the Philosopher University, Faculty of Natural Sciences, Department of Mathematics, \\ Tr. A. Hlinku 1, 94974 Nitra, Slovak Republic \\ ${ }^{3}$ Institute of Laboratory Research on Geomaterials, Faculty of Natural Sciences, Comenius University in Bratislava, \\ Ilkovičova 6, 84215 Bratislava, Slovak Republic \\ ${ }^{4}$ Institute of Botany of the Czech Academy of Sciences, Dukelská 135, CZ-379 82 Třeboň, Czech Republic \\ ${ }^{5}$ University of Ss. Cyril and Methodius, Department of Ecochemistry and Radioecology, \\ J. Herdu 2, Trnava, SK-917 01, Slovak Republic \\ ${ }^{6}$ Comenius University in Bratislava, Faculty of Natural Sciences, Department of Plant Physiology, \\ Ilkovičova 3278/6, Bratislava, 841 04, Slovak Republic
}

Received: 6 May 2020

Accepted: 27 September 2020

\begin{abstract}
Nitrogenous nutrition influences the availability of other plant resources and, consequently, affects plant defense responses. Both a shortage and excess of $\mathrm{N}$ impact plants' ability to accumulate and survive metals/metalloids, but available data are still fragmented and often contradictory. A series of 8 different $\mathrm{NH}_{4} \mathrm{NO}_{3}$ concentrations, ranging from zero to excessive nitrogen (35 $\left.\mathrm{mM} \mathrm{N}\right)$, was applied in growth media to hydroponically grown wheat (Triticum aestivum). The plants were grown at a sublethal concentration of arsenic $\left(5 \mathrm{mM} \mathrm{As}^{3+}\right)$ for 10 days and foliar accumulation of As, $\mathrm{N}$ and $\mathrm{P}$ was determined. In addition, induction of defense-related chitinase and $\beta-1,3$-glucanase enzyme isoforms was quantified upon the separation of plant protein extracts in polyacrylamide gels. $\mathrm{As}^{3+}$ interfered with $\mathrm{N}$ and $\mathrm{P}$ accumulation in shoots and strongly activated several enzyme isoforms. These responses varied with the $\mathrm{N}$ supply and indicated a low rate of As accumulation at low $\mathrm{N}$ concentrations. On the other hand, limited As transfer to shoots was a clear benefit at high $\mathrm{N}$ concentrations. Nevertheless, both extreme $\mathrm{N}$ concentrations restricted the growth. Several enzyme isoforms of both chitinases and $\beta$-1,3-glucanases exerted sensitivity to $\mathrm{As}^{3+}, \mathrm{N}$ supply or both. Their individual responses, however, contradict the generally accepted view on positive correlation between these defense molecules and $\mathrm{N}$ nutrition. Impacts of interplay between $\mathrm{As}^{3+}$ toxicity and nutritional
\end{abstract}

*e-mail: bardacova.monika@gmail.com 
stress on wheat responses are discussed. The results might contribute to knowledge applicable in efficient fertilization and food safety strategies.

Keywords: inducible defense, glucanhydrolases, metalloid toxicity, PR-proteins, trade-off

\section{Introduction}

Both nitrogen (N) shortage and excess severely affect plants. When acting for longer periods, $\mathrm{N}$ starvation mainly restrains the synthesis of nucleic acids and enzymes [1]; on the other hand, stagnant nutrient solutions exceeding $10 \mathrm{mM}$ nitrate decelerates plant growth [2,3]. Compared to $\mathrm{N}$ shortage, $\mathrm{N}$ toxicity is rare in nature, however, over-fertilization of agricultural soils has become a serious environmental problem in recent decades. For some plant species, a threshold of $25 \mathrm{mM} \mathrm{N}$ has been determined for toxicity [4 and therein].

A growing body of evidence suggests that the nutritional status of plants not only limits plant growth but also determines the availability of resources for defense. Data indicate that nitrate transporters affect the outcomes of different plant-pathogen interactions by mediating ROS production, regulating salicylic acid (SA) signaling towards the resistance by safeguarding energy, and/or by accumulating certain metabolites $[5,6]$. $\mathrm{N}$ addition to plants seems to generally reduce the content of secondary metabolites such as e.g. the diverse groups of phytoalexins [7], while the accumulation of other compounds such as terpenes or alkaloids showed more variable correlations with $\mathrm{N}$ supply [8]. Since many of these compounds possess antimicrobial activity, it is not surprising that excessive $\mathrm{N}$ often results in compromised resistance against microbial pathogens [9]. However, opposite responses have been reported for antimicrobial proteins, albeit the impact of $\mathrm{N}$ availability on inducible defense components has been relatively poorly studied, especially in relation to abiotic stress. Several studies on plant responses to different fertilizer regimes confirmed (often unwittingly) the $\mathrm{N}$ impact on individual defense-related enzymes such as chitinases [10-12], peroxidases [8] and $\beta$-1,3-glucanases [13]. Generally, the activities of these enzymes correlated positively with excessive $\mathrm{N}$ supply $[8,10]$, but recently much more peculiar, $\mathrm{N}$-specific responses have been demonstrated in wheat grown within a broad range of $\mathrm{N}$ supply/availability [3]. In the last study, the behaviour of the individual isoforms probably reflected a variable $\mathrm{NO}_{3}$ - sensitivity and/or efficiency of different nitrate transport systems in plants [14]. More importantly, it suggests possible consequences to the defense ability of plants [3].

Arsenic (As) is a toxic metalloid element that enters natural geochemical processes, but due to different anthropogenic activities (e.g. mining, use of pesticides and fertilizers etc.), it increasingly contaminates soils and water and poses serious health risk to plants as well as animals and humans $[15,16]$. Though it can be beneficial at very low soil contents [17], at higher concentrations it is generally toxic to plants and hampers many physiological processes. Arsenic enters the plants in sap-mobile $\mathrm{As}^{3+}$ or $\mathrm{As}^{5+}$ forms through transporters of other elements (mainly $\mathrm{P}$ and $\mathrm{Si}$ ) and through water-channel proteins [18]. While $\mathrm{As}^{5+}$ is readily reduced to $\mathrm{As}^{3+}$ as a first step of detoxification, in non-hyperaccumulating plants, the reduced $\mathrm{As}^{3+}$ is the main As form that may be sequestered to vacuoles following complexation with phytochelatins and subsequent transport via ABC (ATP Binding Cassette) transporters [19]. Recently, inositol transporters (INTs) have been recognized to perform As loading to phloem [20].

Early after exposure, As triggers an unavoidable burst of deleterious oxidative stress which is eliminated by the plant's antioxidative apparatus accumulating various low-molecular weight compounds (e.g. ascorbate, glutathione, phytochelatins, etc.) and/or by activity of detoxification enzymes (catalases, peroxidases, superoxide dismutases, etc.) [15]. Arsenic disrupts vital cellular processes by binding to thiol groups and co-factors of enzymes $\left(\mathrm{As}^{3+}\right)$, or by replacing $\mathrm{P}$ in important biochemical reactions $\left(\mathrm{As}^{5+}\right)$. The binding of $\mathrm{As}^{3+}$ to thiols represents the key detoxification mechanism of both forms and results in the retention of a major part of As taken up by plants in roots [16]. Similar to many typical heavy metals like Cd or $\mathrm{Pb}$, As impairs photosynthetic performance [21,22], but does not strongly affect genes related to carbon metabolism [15]. On the contrary, As causes dramatic changes in nitrogen transport and metabolism, altering the amino acid pools and energetic balance in cells [24]. There are few reports on how As affects different defense enzymes. Inhibitory but also activating effects have been reported for antioxidative enzymes [23, 25], chitinases in soybean, barley and maize [26], and for $\beta$-1,3-glucanases in maize and soybean [27]. The latter two enzymes re-modulate the cell wall composition, affect metabolite trafficking [28] and/ or generate signaling molecules to trigger downstream defense cascades after a plant's exposure to metal(loid) toxicity [21, 29], cold and drought [30,31]. Since several of them play pivotal roles in many morphological and developmental processes as well $[32,33]$, they represent a good system to sensitively monitor the changes in both environmental conditions and developmental processes.

This work aims to reveal the character of changes in the previously-described plant responses to a broad range of $\mathrm{N}$ supply [3] with exposure to concurrent abiotic stress. In wheat plants exposed to sublethal dose of arsenic and $\mathrm{NH}_{4} \mathrm{NO}_{3}$ nutrition ranging between starvation to excess (toxicity), we studied the patterns 
and activities of $\beta$-1,3-glucanase and chitinase enzymes. We aimed to i) reveal their sensitivity to arsenic stress, ii) evaluate the influence of $\mathrm{N}$ availability on the observed responses and iii) to estimate the effect of $\mathrm{N}$ supply on As uptake, plant vitality and tolerance. In contrast with most of the previously published studies, As was applied as $\mathrm{As}^{3+}$ and our discussion relates to this more toxic form.

\section{Experimental Procedures}

\section{Plant Material, Cultivation and Experimental Design}

Wheat (Triticum aestivum L. cv. Genoveva) was grown in a mineral nutrient solution [3]. Uniform seeds germinated on wet filter paper were transferred to constantly aerated plastic containers $(15 \times 15 \times 20 \mathrm{~cm})$ with $700 \mathrm{ml}$ of basic Hoagland solution containing $0.2 \mathrm{mM} \mathrm{NH}_{4} \mathrm{NO}_{3}, 5.0 \mathrm{mM} \mathrm{KNO}, 2.0 \mathrm{mM} \mathrm{Ca}\left(\mathrm{NO}_{3}\right)_{2}$,

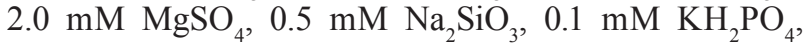
$50 \mu \mathrm{M} N a F e\left(\right.$ III)EDTA, $50 \mu \mathrm{M} \mathrm{H}_{3} \mathrm{BO}_{3}, 5 \mu \mathrm{M} \mathrm{MnCl}_{2}$, $5 \mu \mathrm{M} \mathrm{ZnSO}_{4}, 0.5 \mu \mathrm{M} \mathrm{CuSO}_{4}$, and $0.1 \mu \mathrm{M} \mathrm{Na} \mathrm{MoO}_{3}$. In experimental variants, $\mathrm{KNO}_{3}$ was fully replaced by $\mathrm{K}_{2} \mathrm{SO}_{4}$ and $\mathrm{Ca}\left(\mathrm{NO}_{3}\right)_{2}$ by $\mathrm{CaCl}_{2}$ to modify the content of $\mathrm{N}$ (supplied solely in the form of $\mathrm{NH}_{4} \mathrm{NO}_{3}$ ) to the final total nitrogen concentrations of $0,0.75$ and $5.25 \mathrm{mM}$ $\mathrm{N}$ (suboptimal concentrations), $7.5 \mathrm{mM} \mathrm{N}$ (optimal; comparable to the basic Hoagland solution), and 15, 25,30 and $35 \mathrm{mM} \mathrm{N}$ (excess of $\mathrm{N}$ ) [3]. On the basis of former trials, the solution was not exchanged. An additional set of the nitrogenous variants was supplemented with $\mathrm{As}^{3+}$ at a sublethal concentration of $5 \mathrm{mM}$, prepared from $\mathrm{As}_{2} \mathrm{O}_{3}$ [34]. The plants were grown in a climate-controlled chamber at $22^{\circ} \mathrm{C}$ (6 a.m. to 6 p.m.) and $18^{\circ} \mathrm{C}$ (6 p.m. to 6 a.m.) at a relative humidity of $60 \%, 16 / 8 \mathrm{~h}$ photoperiod and irradiance $300-400 \mu \mathrm{mol} / \mathrm{m}^{2}$.s of PAR. Leaf and root tissue was sampled 10 days after cultivation in presence of As. Arsenic was removed from roots by washing with $0.5 \mathrm{mM}$ EDTA twice for $\sim 1 \mathrm{~min}$ and rinsing with distilled water. A set of plants was dried at $80^{\circ} \mathrm{C}$ to constant weight to measure the dry weight (DW) of shoots and roots, and determine the content of elements (see below). For other analyses, the organs were frozen in liquid nitrogen and stored at $-80^{\circ} \mathrm{C}$. The experiment was repeated 9 times independently in a randomized complete block design with one container with 15 plants ( $\mathrm{n}=135$ plants per variant).

\section{Tissue Content of Nutrients and Arsenic}

Tissue organic nitrogen and phosphorus contents in leaf tips where analyzed following acid mineralization of the samples. Three experimental replicates per variant were quantified colorimetrically with an automatic FIAstar 5010 Analyzer (Tecator, Sweden); for details, see [35]. Since most of the nitrate taken up by roots is transported to the shoots in wheat, roots were not assayed [36]. Leaves and root samples were mineralized in a $\mathrm{HNO}_{3}$ and $\mathrm{H}_{2} \mathrm{O}_{2}$ mixture (Anton Paar Multiwave 3000) and the As content was measured using ICP-MS (Perkin Elmer Elan 6000). For validation, certified reference materials NCS DC73349 and NCS DC73350 (China) were used.

\section{Assays of Chitinases and Glucanases}

Proteins were extracted from tissues as per [37]. A sample was taken as a pool of three individual plants per variant, and the enzyme analyses were performed in samples from three experimental replicates from each variant $(n=9$ plants per variant). The activity of $\beta$-1,3-glucanases was determined with a 3,5-dinitrosalicylic acid (DNS) method [38]. The total chitinase activity in samples was measured fluorimetrically (Fluoroskan II microtiterplate reader, TITERTEK, Finland). Protein extracts $(20 \mu \mathrm{l})$ were mixed with $30 \mu \mathrm{l}$ of $300 \mu \mathrm{M}$ 4-methylumbelliferyl- $\beta$-D$N, N^{\prime}, N^{\prime \prime}$-triacetylchitotrioside in $0.1 \mathrm{M}$ sodium citrate

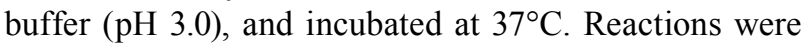
stopped by addition of $150 \mu \mathrm{l}$ of $0.2 \mathrm{M} \mathrm{Na}_{2} \mathrm{CO}_{3}$ after 1 hour. Fluorescence was measured using excitation and emission filters $355 \mathrm{~nm} / 450 \mathrm{~nm}$ and the enzyme activity was expressed as picomoles of methylumbelliferone generated per $\mu \mathrm{g}$ of soluble protein per hour.

For enzyme profile analyses, proteins $(20 \mu \mathrm{g})$ were separated in $12.5 \%(\mathrm{w} / \mathrm{v})$ polyacrylamide gels under standard conditions. The gels contained $0.01 \%(\mathrm{w} / \mathrm{v})$ glycol chitin or $0.01 \%(\mathrm{w} / \mathrm{v})$ laminarin (Sigma) as enzyme substrate. Enzyme profiles, profiles of acidic/ neutral and basic/neutral isoforms (respectively) were detected after washing the gels in $50 \mathrm{mM}$ sodium acetate buffer ( $\mathrm{pH}$ 5.0) with $1 \%(\mathrm{v} / \mathrm{v})$ Triton X-100 overnight. Chitinases were stained with $0.01 \%(\mathrm{w} / \mathrm{v})$ Fluorescent Brightener 28 (Sigma) as described by [39]. The glucanase fractions were stained with 2,3,5-triphenyltetrazolium chloride (Sigma) [39]. As a measure of the enzyme activity, background-corrected integrated density (ID) of the bands was quantified using Scion Image software (http://www.scioncorp. com) [21]. The size of isoforms was determined as based on co-separated marker proteins after standard Coomassie-staining of gels. As isoforms separated only on the basis of their size can contain several isoforms of similar size, the conclusive value of these data might be limited; therefore, their patterns are not described in detail. Nevertheless, they were included in star icon plots to give a complete view on the extent of detected changes. Statistical evaluation of all the data is available in Supplement S1.

\section{Statistical Analyses}

One-way ANOVA and a Tukey post-hoc test, separately for shoots and roots, were performed to estimate the effects of nitrogen concentration in growth 

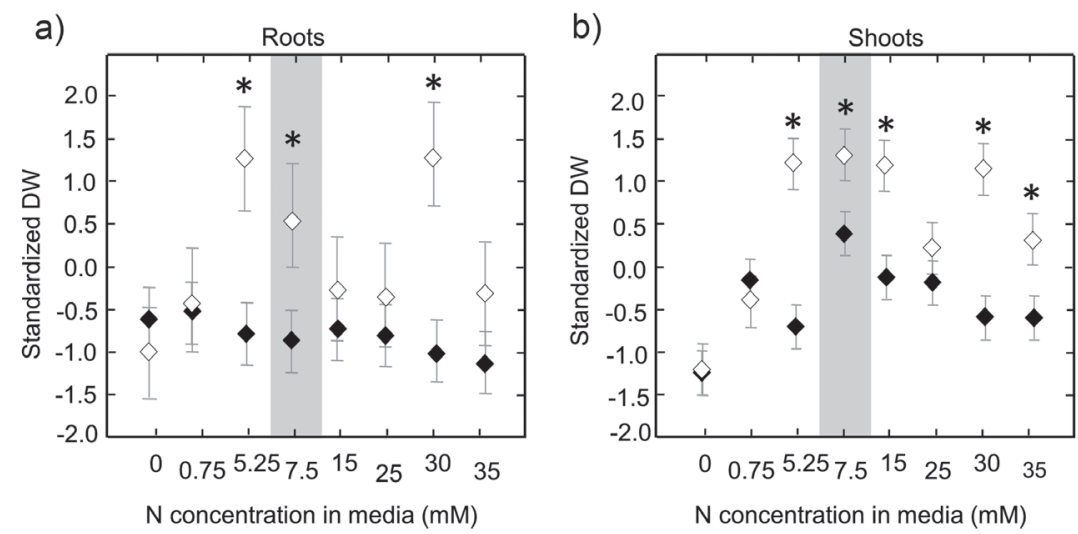

Fig. 1. Effect of $5 \mathrm{mM} \mathrm{As}^{3+}$ at different $\mathrm{N}$ concentrations in growth media on dry biomass of roots a), and shoots b) in absence (empty labels) or presence of $\mathrm{As}^{3+}$ (filled labels). Standardized average values of 5 plants per variant ( $\mathrm{n}=9$ repetitions) with $95 \%$ confidential intervals are shown. Asterisks indicate a statistical significance for the As effect in individual variants at $p<0.05$. Details on significance of $\mathrm{N}$ effects are given in Table S1.

media on the tested plant parameters. The relationship between the parameters was examined by a Spearman correlation coefficient. For clarity, the data for individual parameters were standardized $(z)$ as $z=(x-\mu) / \sigma$, while $x$ is the actual value of the parameter in a variant, $\mu$ is the average value of all variants and $\sigma$ is the standard deviation for the given parameter. Standardized values of all parameters are presented as star icon plots that indicate the impact of $\mathrm{N}$ concentration. Each ray represents a different variable and its length represents the relative value of a particular variable. An overview of the statistical significance for the discussed parameters is given in Supplementary Table S1.

\section{Results}

\section{Plant Growth}

Nitrogen in media at both sub- and supra-optimal concentrations restricted plant growth and resulted in lower dry weights compared to optimal concentrations (Fig. 1a,b). An additional decrease of shoot dry mass was apparent in response to As in the media ( $p<0.001$, $\mathrm{F}=54.51)$ at $5.25,15$ and $30 \mathrm{mM} \mathrm{N}$ (Fig. 1b). The interaction between the effects of the two (stress) factors is significant $(\mathrm{p}<0.001, \mathrm{~F}=6.14$; Table $\mathrm{S} 1)$. Similar effects were obvious for roots at 5.25 and $30 \mathrm{mM} \mathrm{N}$ as well (Fig. 1a).

\section{Content of Elements}

The relationship between $\mathrm{N}$ supply and its content in shoot tissue was convex, confirming the lowest $\mathrm{N}$ contents at limiting $\mathrm{N}$ concentrations. Arsenic toxicity disturbed this trend at concentrations $\leq 15 \mathrm{mM} \mathrm{N}$ and generally decreased the shoot $\mathrm{N}$ content (Fig. 2a). Exceptions were the increased $\mathrm{N}$ content in starving plants and the absence of any change at the optimal $7.5 \mathrm{mM} \mathrm{N}$ (Fig. 2a). The content of P in shoots, itself not dependent on nutrition up to $30 \mathrm{mM} \mathrm{N}$ [3], varied in response to As at $\geq 7.25 \mathrm{mM} \mathrm{N}$ in media (Fig. 2b).
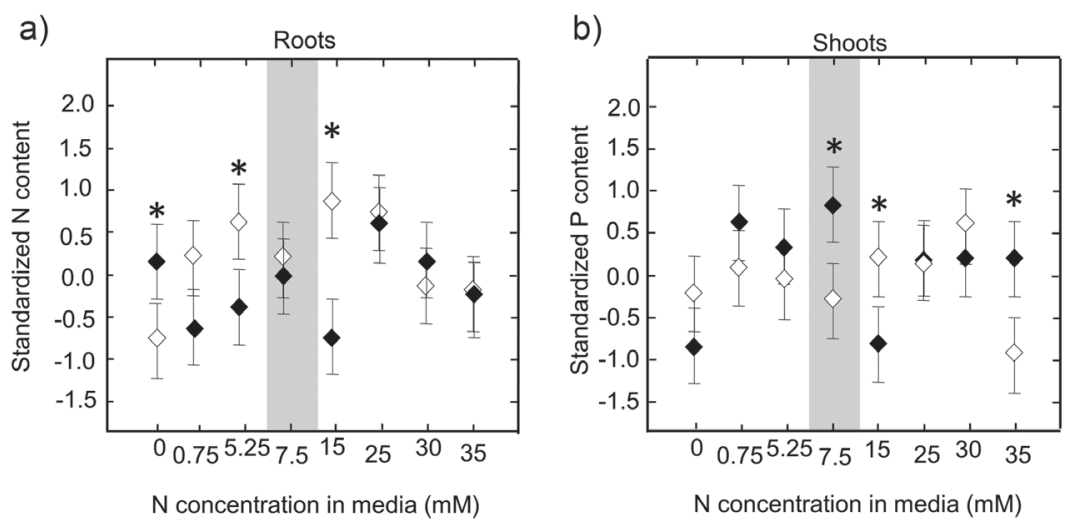

Fig. 2. Effect of $5 \mathrm{mM} \mathrm{As}^{3+}$ at different $\mathrm{N}$ concentrations in growth media on content of $\mathrm{N}$ a) and $\mathrm{P}$ b) in shoots when grown in absence (empty labels) or presence of $\mathrm{As}^{3+}$ (filled labels). Standardized average values with $95 \%$ confidential intervals $(\mathrm{n}=3)$ are shown. Asterisks indicate a statistical significance for the As effect in individual variants at $\mathrm{p}<0.05$. Details on significance of $\mathrm{N}$ effects are given in the Table S1. 

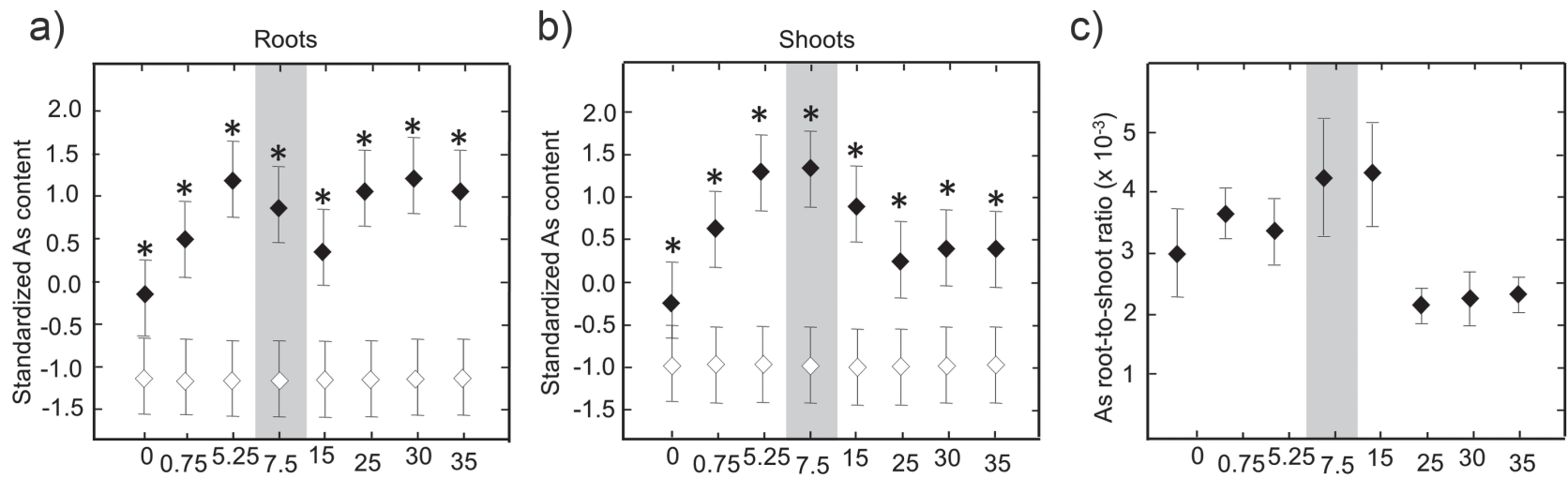

Fig. 3. Influence of $5 \mathrm{mM} \mathrm{As}^{3+}$ at different $\mathrm{N}$ concentrations in growth media on As content ( $\left.\mathrm{g}^{-1} \mathrm{DW}\right)$ in roots a) and shoots b) and on rootto-shoot As content ratio c). Data show values in tissues grown in absence (empty labels) or presence of $\mathrm{As}^{3+}$ (filled labels). Standardized average values with $95 \%$ confidential intervals $(n=3)$ are shown. Asterisks indicate statistical significance for As effect in individual variants at $\mathrm{p}<0.05$. Details on significance of $\mathrm{N}$ effects are given in the Table $\mathrm{S} 1$.

Elevated $\mathrm{P}$ levels were measured in shoots at 7.5 and $35 \mathrm{mM} \mathrm{N}$, but less $\mathrm{P}$ was recorded at $15 \mathrm{mM} \mathrm{N}$ (Fig. 2b).

Arsenic accumulated predominantly in wheat roots. The accumulation rate was markedly affected by nitrogen availability in the range of $0-5.25 \mathrm{mM}$ $\mathrm{N}$ (for both tissue types $\mathrm{p}<0.05$; Fig. 3). Only $129.7 \pm 12.0$ (SE) $\mu \mathrm{g}^{-\mathrm{g}^{-1}}$ As was detected in poorly fed roots, in contrast to the highest As content of $350.8 \pm 17.2 \mu \mathrm{g} . \mathrm{g}^{-1}$ recorded at $5.25 \mathrm{mM} \mathrm{N}$ (Table S2). At other optimal $\mathrm{N}$ concentrations, the root As content slightly dropped or remained at comparable levels at high $\mathrm{N}$ concentrations. A low amount of As was translocated to shoots. The highest average As content in shoots $\left(1.28 \pm 0.61 \mu \mathrm{g} . \mathrm{g}^{-1}\right)$ was recorded at $\mathrm{N}$ concentrations close to the optimum (Fig. 3b). The shoot-to-root ratio of As content appeared lower at high $\mathrm{N}$ supply (Fig. 3c). However, neither the influence of $\mathrm{N}$ availability, As accumulation nor their interactive effects on the content of assayed elements was statistically significant for the complete set of experimental plants (Suppl. Table S1), indicating complexity of the underlying As uptake mechanisms.

\section{Enzyme Activity of PR Proteins}

A profound effect of $\mathrm{N}$ nutrition conditions on activity of PR proteins has been reported [3] and a possible impact on the defense mechanism under stress has been expected.

\section{Chitinases}

The overall activity of chitinases in wheat tissues markedly varied in response to As as dependent on $\mathrm{N}$ nutrition. In roots, activity levels were suppressed mostly at low as well as $\geq 15 \mathrm{mM} \mathrm{N}$ concentrations (Fig. 4a). Unlike in shoots, enhancement of enzyme activity was marked except for the two highest $\mathrm{N}$ concentrations (no effect or suppression; Fig. 4b).
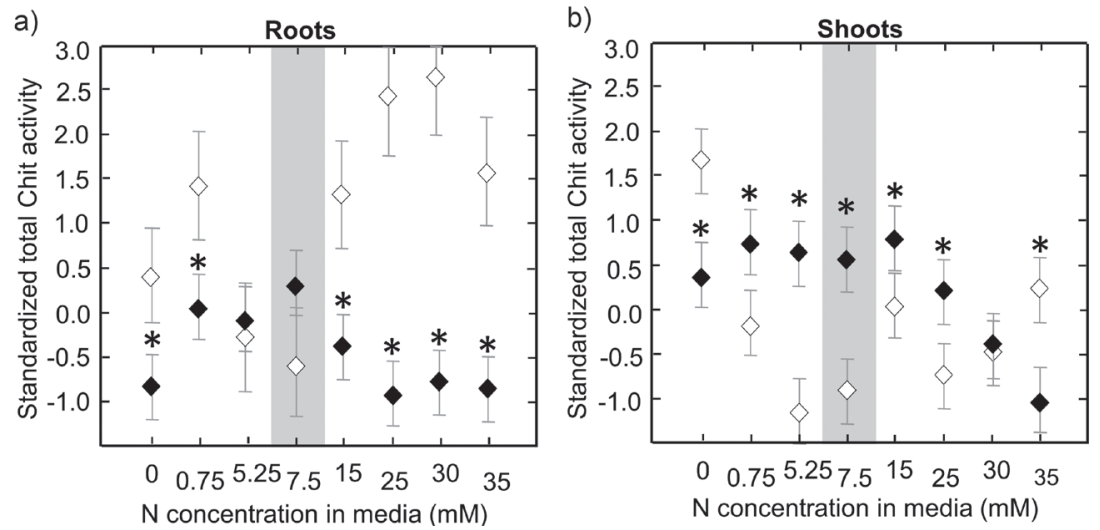

Fig. 4. Influence of $5 \mathrm{mM} \mathrm{As}^{3+}$ at different $\mathrm{N}$ concentrations in growth media on total activity of chitinases in roots a) and shoots b). Data indicate activity in absence (empty labels) or presence of $\mathrm{As}^{3+}$ (filled labels). Standardized average values with $95 \%$ confidential intervals $(\mathrm{n}=3)$ are shown. Asterisks indicate a statistical significance for the As effect in individual variants at $\mathrm{p}<0.05$. Details on significance of $\mathrm{N}$ effects are given in the Table $\mathrm{S} 1$. 
a)

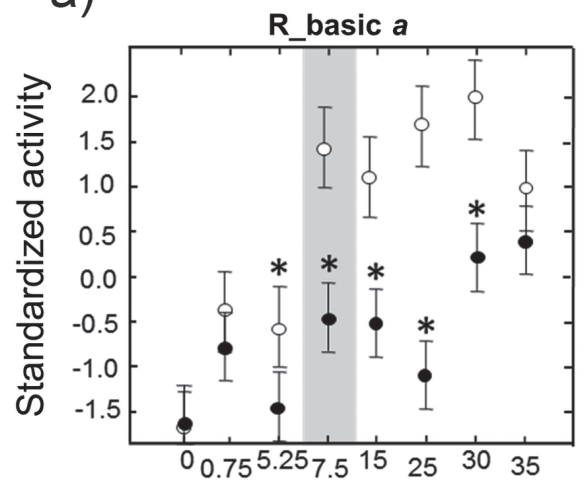

d)

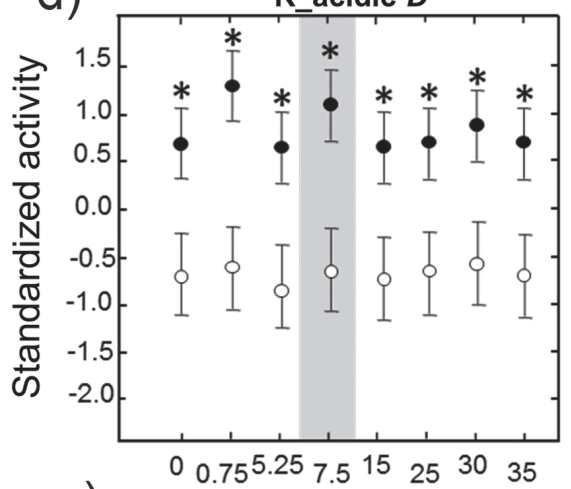

g)

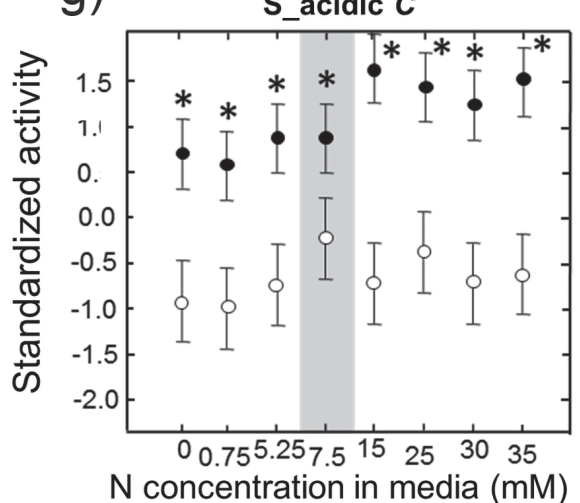

b)

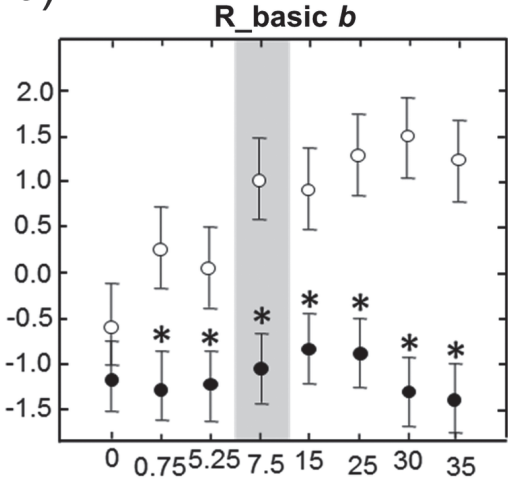

e)

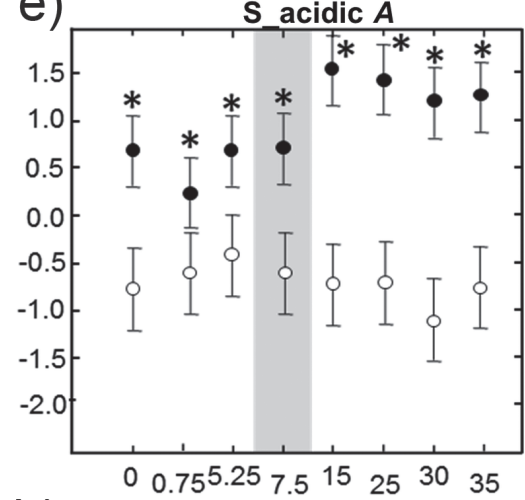

h)

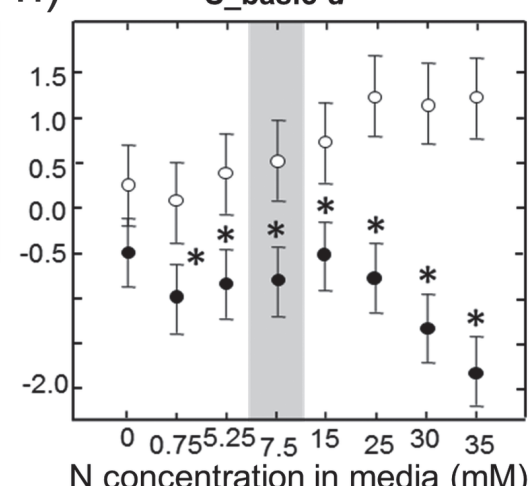

c)

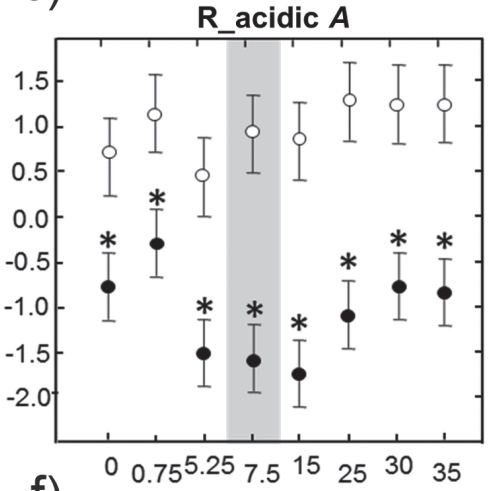

f)

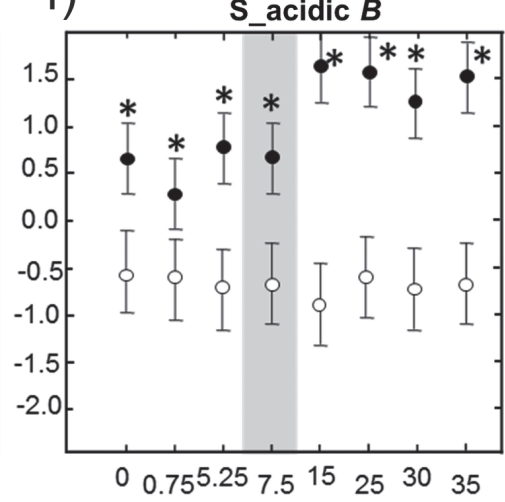

$\mathrm{N}$ concentration in media $(\mathrm{mM})$ i)<smiles>C=C(C)CC</smiles>

0

0.75
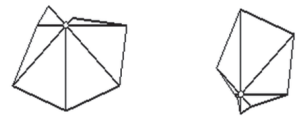

5.25

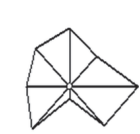

7.5

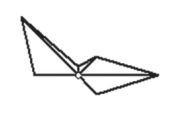

15

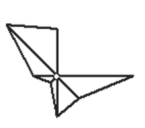

25

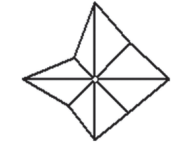

30

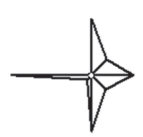

35

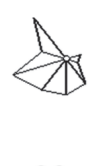

30

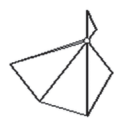

35

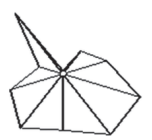

15

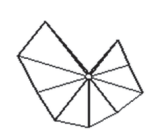

25

Fig. 5. Effect of $5 \mathrm{mM} \mathrm{As}^{3+}$ on activities of individual chitinases as dependent on $\mathrm{N}$ concentrations in growth media. The isoforms were detected in roots (a-d) and shoots (e-h) when grown in absence (empty labels) or presence of $\mathrm{As}^{3+}$ (filled labels). The star plots display the relative activity change of each quantified chitinase under stress, while rays correspond to individual isoform in roots (I, 8 items) and shoots (J, 10 items) at different $\mathrm{N}$ concentrations indicated below plots (in $\mathrm{mM}$ ). In graphs, standardized average activity values with $95 \%$ confidential intervals $(\mathrm{n}=3)$ are shown. Different letters indicate significance at $P<0.05$. Chitinases given in star plots denote clockwise order from twelve o' clock position for 70, $50 \mathrm{kDa}$, basic $a$ - $d$, acidic $A-D$ (roots) and $65,48,40,35 \mathrm{kDa}$, basic $a-d$, acidic $A-D$ (shoots). Asterisks indicate a statistical significance for the As effect in individual variants at $\mathrm{p}<0.05$. Details on significance of $\mathrm{N}$ effects are given in the Table S1. 
a)

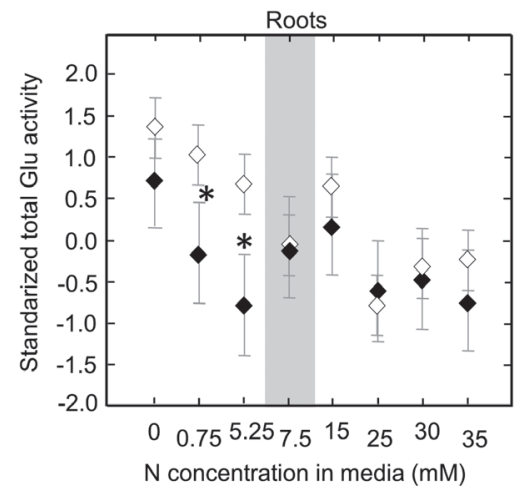

b)

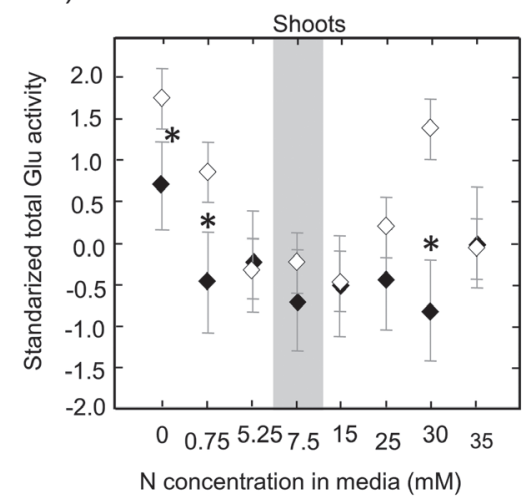

Fig. 6. Influence of $5 \mathrm{mM} \mathrm{As}^{3+}$ at different $\mathrm{N}$ concentrations in growth media on total activity of $\beta$-1,3-glucanases in roots a) and shoots b). Data indicate activity in absence (empty labels) or presence of $\mathrm{As}^{3+}$ (filled labels). Standardized average values with $95 \%$ confidential intervals $(n=3)$ are shown. Asterisks indicate a statistical significance for the As effect in individual variants at $\mathrm{p}<0.05$.

The interaction of As and nutrition on chitinases was significant only in shoots $(\mathrm{p}<0.001, \mathrm{~F}=6.21)$.

For a more detailed analysis of chitinase enzymes in wheat tissues, we detected and quantified the activities of individual isoforms in separation gels. Two chitinase fractions detected in roots (70 and $50 \mathrm{kDa})$ comprised at least 4 acidic/neutral $(A-D)$ and 4 basic/neutral $(a-d)$ isoforms (Fig. S1), and half of them did respond to As. The acidic isoform $C$ and the basic isoforms $a$ and $b$ appeared significantly inhibited by As (Fig. 5a-c), as opposed to the induced acidic isoform $D$ (Fig. 5d). Some of these isoforms were significantly influenced by $\mathrm{N}$ conditions as well; the acidic $A$ chitinase exerted relatively higher activities at both sub- and supraoptimal $\mathrm{N}$ concentrations, as opposed to the basic isoform $b$ with generally low activities. The negative effect of As on the basic isoform $a$ seems to be the strongest at optimal $\mathrm{N}$ but declines with better nutrition. The interaction of the As effect and the $\mathrm{N}$ supply was significant for the isoforms $C$ and $b$ (Suppl. Table S1).

Chitinases of four different sizes were detected in shoots $(65,48,40$ and $35 \mathrm{kDa})$, comprising at least 4 acidic/neutral $(A-D)$ and 4 basic/neutral $(a-d)$ isoforms (Fig. S1). Three acidic chitinases responded to As with significant induction, mainly at optimal or high $\mathrm{N}$ supply (Fig. 5e-g). Though we could not statistically support the effect of $\mathrm{N}$ for the whole plant set, the interactive effect of $\mathrm{N}$ with As was significant for isoforms $B$ and $C$ (Fig. 5f, g, Table S1). A single basic chitinase isoform (d) was inhibited by As (Fig. 5h), mainly at optimal or high $\mathrm{N}$ nutrition levels. Neither the effect of $\mathrm{N}$ at all concentrations nor the interactive effect with As were significant for this isoform (Table S1).

The icon plots of all quantified wheat chitinases (including those separated as based solely on size) summarize the relative activity values (responses) of individual isoforms, expressed as rays of corresponding sizes (Fig. 5i, j). The plots reflect variable responses of several chitinase isoforms to As toxicity, and suggest a considerable non-linear impact of $\mathrm{N}$ availability.

\section{$\beta$-1,3-glucanases}

The total activity of $\beta$-1,3-glucanases appeared to be suppressed by As in both organs (Fig. 6). This effect was observed at $\leq 5.25 \mathrm{mM} \mathrm{N}$ in roots $(p<0.001$, $\mathrm{F}=131.6$ ), and at both low and high $\mathrm{N}$ concentrations in shoots $(\mathrm{p}<0.001, \mathrm{~F}=34.0)$. The combined effects of As and nutrition on these enzymes was, however, significant only in shoots $(\mathrm{p}<0.001, \mathrm{~F}=6.41$; Table $\mathrm{S} 1)$. Up to four $\beta$-1,3-glucanases were detected in roots $(150,68,45$ and 35 kDa; Fig. S1; Fig. 7). Separation under native conditions revealed 4 acidic isoforms $(A-D)$, of which only the $C$ isoform was inhibited by As $(\mathrm{p}<0.01, \mathrm{~F}=18.8)$ but only at $\leq 7.5 \mathrm{mM} \mathrm{N}$ (Fig. 7a). The interaction of this effect with $\mathrm{N}$, however, was not significant (Table S1). On the other hand, both detected basic isoforms were activated by As at optimal nutrition or slightly higher $\mathrm{N}$ (isoform $a$ ), or with no obvious pattern regardless of the $\mathrm{N}$ supply (isoform $b$; Fig. 7b,c; Table $\mathrm{S} 1$ ). For the former basic isoform, we confirmed the effect of $\mathrm{N}$ supply $(\mathrm{p}<0.01$, $\mathrm{F}=3.34)$ as well as of its interaction with $\mathrm{As}(\mathrm{p}<0.001$, $\mathrm{F}=5.63$ ).

At least five $\beta-1,3$-glucanases of different sizes were present in shoots $(150,68,50,38$ and $30 \mathrm{kDa})$, however, we detected only two acidic and a single basic isoform in native gels upon charge separation (Fig. S1; Fig. 7d,e). The acidic isoforms $A$ and $B$ were significantly induced in the presence of As and the former shows responsiveness to $\mathrm{N}$ conditions as well $(p<0.001, F=6.99)$. Importantly, the interactive effect of As and $\mathrm{N}$ was significant for both isoforms (Table S2) and the basic isoform was not induced by either studied factor. The icon plots of all quantified wheat $\beta$-1,3-glucanases (including those separated by size) suggest more decreased activities by As at limiting $\mathrm{N}$ concentrations in both organs. In shoots, the amplitudes of changes were highest at $\mathrm{N}$ concentrations between 15-30 mM N in media (Fig. 7 f,g). 
a)

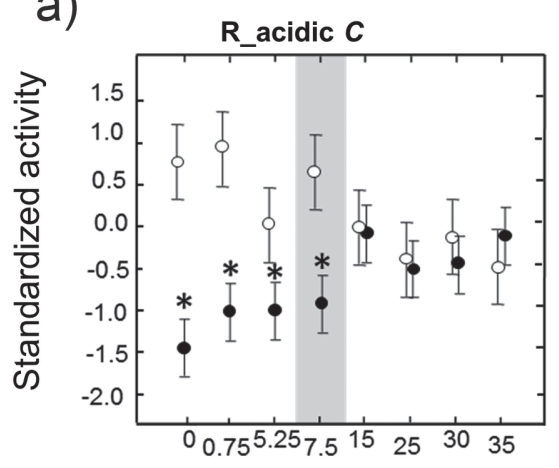

d)

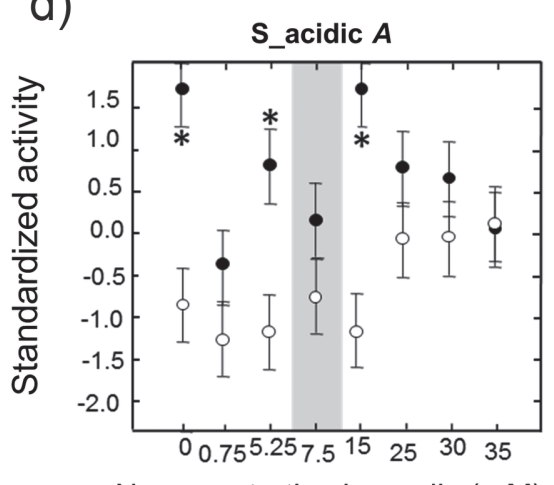

$\mathrm{N}$ concentration in media $(\mathrm{mM})$ b)

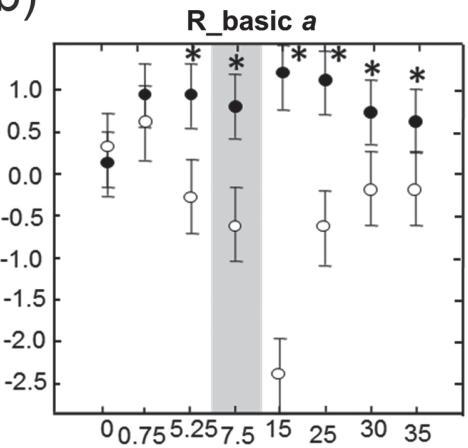

e)

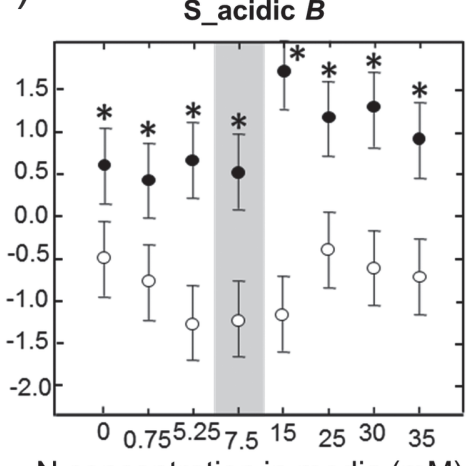

c)

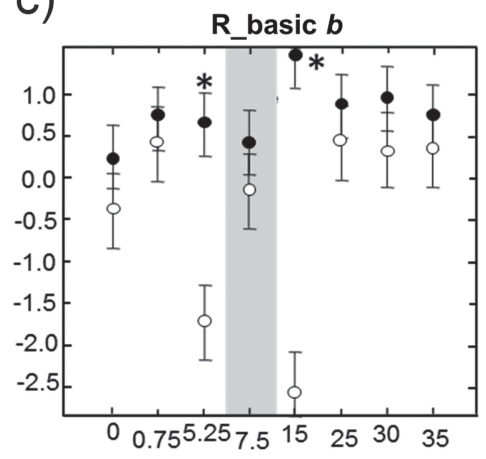

$\mathrm{N}$ concentration in media (mM)

$\mathrm{N}$ concentration in media $(\mathrm{mM})$

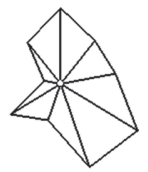

7.5

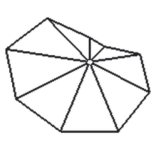

15

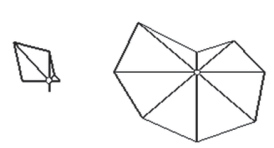

7.5

$$
5
$$

15
5.25

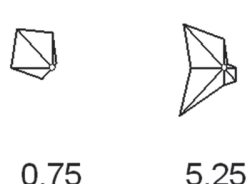

0.75

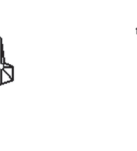

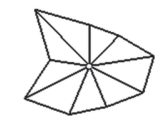

25

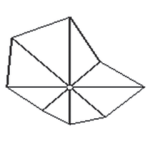

25

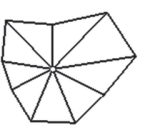

30

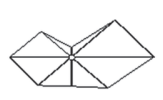

30

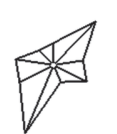

35

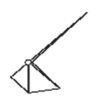

35

Fig. 7. Effect of $5 \mathrm{mM} \mathrm{As}^{3+}$ on activities of individual $\beta$-1,3-glucanases at different $\mathrm{N}$ concentrations in growth media. The isoforms were detected in roots (a-c) and shoots (d-e) when grown in the absence (empty labels) and presence of $\mathrm{As}^{3+}$ (filled labels). The star plots display the relative activity change of each quantified $\beta$-1,3-glucanases under stress, while rays correspond to individual isoforms in roots (f, 9 items) and shoots ( $\mathrm{g}, 8$ items) at different $\mathrm{N}$ concentrations indicated below plots (in $\mathrm{mM}$ ). In graphs, standardized average activity values with $95 \%$ confidential intervals $(n=3)$ are shown. Asterisks indicate a statistical significance for the As effect in individual variants at $\mathrm{p}<0.05$. Beta-1,3-glucanases given in star plots denote clockwise order from twelve o'clock position for $150,68,45,35 \mathrm{kDa}$, acidic $A-D$, basic $a-b$ (roots) and $150,68,50,38,30 \mathrm{kDa}$, acidic $A-B$, basic $a$ (shoots).

\section{Discussion}

Nitrogen nutrition positively coincides with plant amino acid content, but limits the metabolism of organic acids [1]. While both groups of metabolites comprise important defensive compounds, the former are believed to contribute more markedly to disease resistance, at least in relation to biotic stress [41]. Responses of different nitrogenous metabolites (e.g. proline or different enzymes) to stress thus logically depend on $\mathrm{N}$ availability, but the variability of experimental conditions in single studies, limited range of $\mathrm{N}$ concentrations, different forms of supplied $\mathrm{N}$ and other minor differences still generate a limited amount of comparable data to make reliable conclusions.

The effects of the eight different $\mathrm{N}$ concentrations on wheat growth, photosynthetic pigments and some of defense compounds have already been described, and the non-linear pattern of these responses has been emphasized [3]. Our present results showed that the presence of $\mathrm{As}^{3+}$ restricted the growth of experimental wheat plants similarly to some other species [41, 42], 
Table 1. Correlation coefficient $(R)$ of linear regression models between parameters at the presence of $\mathrm{As}^{3+}$ in media and corresponding statistical significance (p).

\begin{tabular}{|c|c|c|c|}
\hline Parameter 1 & Parameter 2 & $R$ & $\mathrm{p}$ \\
\hline \multicolumn{4}{|c|}{ Shoots } \\
\hline $\begin{array}{l}\text { Basic } \beta-1,3- \\
\text { glucanase } b\end{array}$ & $\mathrm{~N}$ in media & 0.88 & 0.004 \\
\hline Basic chitinase $d$ & $\mathrm{~N}$ in media & 0.95 & 0.001 \\
\hline \multicolumn{4}{|c|}{ Roots } \\
\hline Acidic chitinase $A$ & $\mathrm{~N}$ in media & 0.83 & 0.010 \\
\hline Basic chitinase $a$ & $\mathrm{~N}$ in media & 0.76 & 0.028 \\
\hline Basic chitinase $b$ & $\mathrm{~N}$ in media & 0.93 & 0.001 \\
\hline $\begin{array}{l}\text { Total } \beta-1,3- \\
\text { glucanases }\end{array}$ & $\mathrm{N}$ in media & -0.83 & 0.010 \\
\hline $\begin{array}{l}\text { Total } \beta-1,3- \\
\text { glucanases }\end{array}$ & $\begin{array}{l}\text { Total chiti- } \\
\text { nases }\end{array}$ & -0.81 & 0.015 \\
\hline
\end{tabular}

but more severely at optimal or high $\mathrm{N}$ concentrations (Fig. 1). No effect was observable at low nutrition. This heterogenous effect is likely the result of several factors that interfere with energy production/consumption. First, $\mathrm{As}^{3+}$ reduces photosynthetic rate e.g. by decreasing chlorophyll content [21, 22], inhibiting the enzymes responsible for their synthesis in plastids [43], replacing essential metallic ions such as $\mathrm{Fe}^{2+}, \mathrm{Zn}^{2+}$ and $\mathrm{Mg}^{2+}$ [17] and by hampering ATP and NADPH syntheses [44]. Better $\mathrm{N}$ nutrition can counteract these impacts; $\mathrm{N}$ is not only one of main constituents of chlorophyll and Rubisco [45], but also contributes to the protection of the photosynthetic apparatus providing key players of antioxidation and detoxification such as glutathione (GSH) and phytochelatins (PCs) [46, 47]. Nevertheless, the collinearity of shoot dry weight with tissue $\mathrm{N}$ content was interrupted during the exposure to $\mathrm{As}^{3+}$ (Fig. 2a), confirming the direct interaction of $\mathrm{As}^{3+}$ with $\mathrm{N}$ uptake and metabolism [15].

Arsenic affects tissue nutrient contents as dependent on its chemical form and oxidation stage; unfortunately, reports dealing with $\mathrm{As}^{3+}$ are rather scarce as compared to $\mathrm{As}^{5+}$. Similarly, there are fragmented pieces of knowledge on the potential effects of $\mathrm{N}$ nutrition and its forms on $\mathrm{As}^{3+}$ accumulation. Poorly-fed roots accumulated the lowest amount of $\mathrm{As}^{3+}$, corroborating mild or absent impacts on biomass production. A similar effect of $\mathrm{N}$-deficiency has been described for $\mathrm{As}^{5+}$ in rice roots but not shoots [48], and also for other heavy metals like $\mathrm{Cd}$ in barley [42] or chamomile [49]. Limited $\mathrm{N}$ supply mediated higher $\mathrm{As}^{3+}$ tolerance in algae, though the faster uptake rate indicated an increased amount of responsible transporters [50]; reports on the induced synthesis of such transporters under the low-N conditions are, however, still missing. More importantly, as mentioned above, poor nutrition might limit the potential targets of $\mathrm{As}^{3+}$ toxicity such as
SH-containing proteins and low molecular weight thiols [51]. Their intracellular levels can further decrease through the inhibition of nitrate and nitrite reductases [52], which regulate the assimilation of nitrate and are involved in protein synthesis. The latter scenario is probably of a lesser importance at high $\mathrm{N}$ supply as the $\mathrm{N}$ content in wheat shoots remained unaffected in the presence of As (Fig. 2).

At $\mathrm{N}$ concentration $\geq 25 \mathrm{mM}$, the amount of accumulated $\mathrm{As}^{3+}$ was high in roots but very low in shoots. Possible reasons could be a drop of $\mathrm{pH}$ [53], but in the present experiment it remained unchanged (data not shown). We also exclude a "dilution" of As due to a relatively higher biomass [54]. Root-to-shoot translocation of As species is mostly limited and varies among plant species [55], but apparently alters with $\mathrm{N}$ supply. Restricted accumulation of $\mathrm{As}^{5+}$ has also been observed in rice shoots during the growth in a soil supplemented with $15 \mathrm{mM} \mathrm{N}$ [56]. On the contrary, arsenic alters the uptake and metabolism of other elements in plants. Interference with $\mathrm{P}$ uptake and metabolism is more often discussed for $\mathrm{As}^{5+}$ because of structural similarity with phosphate. Our results revealed that $\mathrm{As}^{3+}$ differently affected tissue $\mathrm{P}$ content in wheat shoots under different conditions of $\mathrm{N}$ supply as a result of several, yet poorly understood and possibly counteracting mechanisms. Comparable $\mathrm{As}^{3+}$ concentrations were reported to inhibit $\mathrm{P}$ uptake [57], while in some species As levels of $50 \mathrm{mg} / 1$ (0.67 mM) were also efficient [58]. Moreover, interrupted water balance, which usually occurs in plant tissues under As stress, decouples the $\mathrm{P}$ and $\mathrm{N}$ cycles [59].

The available nutrient resources for each plant are considered limited, and there exists a trade-off between investments (directing resources) to growth and defense [60]. A surplus of $\mathrm{N}$ has been shown to alleviate the toxicity of $\mathrm{As}^{5+}$, possibly by fuelling and boosting the antioxidative apparatus $[48,56]$. Though the restrained $\mathrm{As}^{3+}$ transfer in well-nourished wheat plants could be considered a sign of tolerance, the associated drop of biomass does question the benefit of high surplus $\mathrm{N}$ on plant vitality. Especially at the most excessive $\mathrm{N}$ concentrations, $\mathrm{N}$ toxicity likely additively contributes to detrimental effects of $\mathrm{As}^{3+}$, e.g. on the contents of some pigments and the growth [22]. Our data on overall activity of chitinases in wheat confirm this; while $\mathrm{N}$ deficiency alone might be responsible (at least partly) for relatively low activity values in roots under both normal and As stress conditions [61], excess of $\mathrm{N}$ apparently strengthened the impact of As toxicity on chitinases and caused suppression of overall activity (Fig. 4a). In shoots, on the other hand, $\mathrm{As}^{3+}$ mostly induces chitinase activity, but this effect mitigates with increasing $\mathrm{N}$ and finally drops to the relatively lowest values (Fig. 4b). An analogous pattern fits for the total activity of $\beta-1,3$-glucanases at $\mathrm{N}$ shortage in shoots. These patterns, however, mask the activity of few isoforms with opposed behaviour; e.g. several acidic chitinases in shoots exert activation by increasing $\mathrm{N}$ 
supply (Fig. 5). Nevertheless, the generally accepted positive correlation between $\mathrm{N}$ nutrition, activity of PR proteins and final resistance [60] apparently should be re-considered or at least handled more carefully since it applies for a few isoforms only (Table 1). Star plots on responses of individual enzyme isoforms show an obvious suppression of several chitinase and $\beta-1,3-$ glucanase members by high $\mathrm{N}$ in roots at the same time point (Figs. 5i,j and 7f,g).

Though the studied enzymes have been widely researched in the context of biotic stress, their role during abiotic stress including tolerance to heavy metals and $\mathrm{As}^{3+}$ remains unclear. Recently, several chitinase and $\beta$-1,3-glucanase transcripts were induced and a few were repressed in rice roots exposed to $\mathrm{As}^{3+}$, while their role in cell-wall biogenesis and/or organisation under metal stress has been proposed [62]. Rapid activation of chitinases has been associated with tolerant genotypes [29], possibly by generating the signals for the activation of downstream responses. For $\beta$-3-glucanases, growing amounts of evidence suggests a regulatory role in plasmodesmal permeability and metabolite trafficking under metal stress via the breakdown of callose [28, 63]. Regardless of their role, in our study, some of these enzymes were responsive to both $\mathrm{As}^{3+}$ and $\mathrm{N}$ supply, confirming the cross-talk between availability/allocation of resources and stress responses [64]. Direct evidence of the activation of these enzymes by $\mathrm{N}$ supply has been reported only for a $\beta$-1,3-glucanase in cotton, where it resulted in the highest fiber strength at optimal, but not at lower or higher $\mathrm{N}$ supply, by hydrolysing $\beta$-1,3-glucan and providing UDP-glucose for cellulose synthesis [65]. The effects on plant tolerance were not tested in the last-mentioned study, but fiber enforcement has been associated with decreased (biotic) stress tolerance [66]. Responsivity of some PR proteins to $\mathrm{N}$ supply has been demonstrated also in wheat [3], rice [62] and poplar [13].

\section{Conclusion}

$\mathrm{As}^{3+}$ ions suppressed wheat growth and altered metabolism of both $\mathrm{N}$ and $\mathrm{P}$ in shoots. On the other hand, $\mathrm{N}$ nutrition supply affected $\mathrm{As}^{3+}$ accumulation and transfer to shoots. Though higher $\mathrm{N}$ supply appears to protect shoots from As toxicity, plant growth and physiological processes are apparently compromised. Responses of studied PR enzymes suggest counterbalancing of actual limitations caused by $\mathrm{N}$ availability and As stress, while the interactive effect of both factors proved significant for several enzyme isoforms. Regardless of the exact biological function of these enzymes, their responses contradict the generally accepted view on the activation of PRs as a result of higher nutrition. At the same time, an optimal $\mathrm{N}$ nutrition needs to be more carefully defined, especially under the conditions of (multiple) stress. Studying the effects of different fertilization regimes on the activity of (defense) enzymes under multiple stresses might bring knowledge for the efficient fertilization and food safety strategies.

\section{Acknowledgements}

This work was financed by the Slovak Research and Development Agency under contract number APVV15-0051 and VEGA 1/0048/19. This study was partly supported (to LA) as a long-term research development project No. RVO 67985939 by the Czech Academy of Sciences. Sincere thanks are due to Dr. Brian M. McMillan (Glasgow, Scotland, U.K.) for English correction of the text.

\section{Conflict of Interest}

The authors report no conflict of interest.

\section{References}

1. XUAN W., BEECKMAN T., XU G. Plant nitrogen nutrition: sensing and signaling. Curr. Opin. Plant Biol. 39, 57, 2017.

2. MOORE J.D., HOULE D. SOIL and sugar maple response to 8 years of $\mathrm{NH}_{4} \mathrm{NO}_{3}$ additions in a base-poor northern hardwood forest. For. Ecol. Manag. 310, 167, 2013.

3. MAGLOVSKI M., GREGOROVÁ Z., RYBANSKÝ L., MÉSZÁROS P., MORAVČÍKOVÁ J., HAUPTVOGEL P., ADAMEC L., MATUŠÍKOVÁ I. Nutrition supply affects the activity of pathogenesis-related $\beta$-1,3-glucanases and chitinases in wheat. Plant Growth Regul. 81 (3), 443, 2017.

4. SÁNCHEZ E., LÓPEZ-LEFEBRE L.R., GARCÍA P.C., RIVERO R.M., RUIZ J.M., ROMERO L. Proline metabolism in response to highest nitrogen dosages in green bean plants (Phaseolus vulgaris L. cv. Strike). J. Plant Physiol. 158, 593, 2001.

5. ZHANG G.B., MENG S., GONG J.M. The expected and unexpected roles of nitrate transporters in plant abiotic stress resistance and their regulation. Int. J. Mol. Sci. 19, 11, 3535, 2018.

6. FAGARD M., LAUNAY A., CLÉMENT G., COURTIAL J., DELLAGI A., FARJAD M., KRAPP A., SOULIÉ M.C., MASCLAUX-DAUBRESSE C. Nitrogen metabolism meets phytopathology. J Exp Bot. 65 (19), 5643, 2014.

7. MUR L. A. J., SIMPSON C., KUMARI A., GUPTA A.K., GUPTA K.J. Moving nitrogen to the centre of plant defence against pathogens. Ann. Bot. 119, 5, 703, 2017.

8. DIETRICH R., PLOSS K., HEIL M. Constitutive and induced resistance to pathogens in Arabidopsis thaliana depends on nitrogen supply. Plant Cell Environ. 27, (7), 896, 2004.

9. THALINEAU E., FOURNIER C., GRAVOT A., WENDEHENNE D., JEANDROZ S., TRUONG H.N. Nitrogen modulation of Medicago truncatula resistance to Aphanomyces euteiches depends on plant genotype. Mol. Plant Pathol. 19, 664, 2018.

10. KONOTOP Y., KOVALENKO M., MATUŠÍKOVÁ I., BATSMANOVA L., TARAN N. Proline application triggers temporal red-ox imbalance, but alleviates 
cadmium stress in wheat seedlings. Pak. J. Bot. 49 (6), 2145, 2017.

11. WANG X., PENG F., YANG L., LI M., ZHANG S. Expression of genes involved in nitrate signaling and metabolism in peach roots in response to elevated levels of nitrate. Plant Mol. Biol. Rep. 30, 1450, 2012.

12. CHANDNA R., AHMAD A. Nitrogen stress-induced alterations in the leaf proteome of two wheat varieties grown at different nitrogen levels. Physiol. Mol. Biol. Pla. 21 (1), 19, 2015.

13. POOVAIAH C.R., PHALEN C., SNIFFEN G.T., COLEMAN H.D. Growth and transcriptional changes in poplar under different nitrogen sources. Plant Mol. Biol. Rep. 37, 291, 2019.

14. MIGOCKA M., WARZYBOK A., PAPIERNIAK A., KŁOBUS G. $\mathrm{NO}_{3}^{-} / \mathrm{H}^{+}$antiport in the tonoplast of cucumber root cells is stimulated by nitrate supply: evidence for a reversible nitrate-induced phosphorylation of vacuolar $\mathrm{NO}_{3}^{-} / \mathrm{H}^{+}$antiport. PLoS One 8, e73972, 2013.

15. FINNEGAN P.M., CHEN W. Arsenic toxicity: The effects on plant metabolism. Front. Physiol. 3, 182, 2012.

16. AWASTHI S., CHAUHAN R., SRIVASTAVA S., TRIPATHI R.D. The journey of arsenic from soil to grain in rice. Front. Plant Sci. 8, 1007, 2017.

17. IMRAN A.A, SAJID Z.A., CHAUDHRY M.N. Arsenic (As) Toxicity to germination and vegetative growth of sunflower (Helianthus annuus L.). Pol. J. Environ. Stud. 24 (5), 1193, 2015.

18. GARBINSKI L.D., ROSEN B.P., CHEN J. Pathways of arsenic uptake and efflux. Environ. Int. 126, 585, 2019.

19. SONG W.Y., YAMAKI T., YAMAJI N., KO D., JUNG K.H., FUJII-KASHINO M., AN G., MARTINOIA E., LEE Y., MA J.F. A rice ABC transporter, OsABCC1, reduces arsenic accumulation in the grain. Proc. Natl. Acad. Sci. USA. 111 (44), 15699, 2014.

20. DUAN G.L., HU Y., SCHNEIDER S., MCDERMOTT J., CHEN J., SAUER N., ROSEN B.P., DAUS B., LIU Z., ZHU Y.G. Inositol transporters AtINT2 and AtINT4 regulate arsenic accumulation in Arabidopsis seeds. Nat. Plants. 2 (1), 15202, 2015.

21. GÁlUSOVÁ T., RYBANSKÝ L', MÉSZÁROS P., SPIEß N., PIRŠELOVÁ B., KUNA R., LIBANTOVÁ J., MORAVČÍKOVÁ J., HAUPTVOGEL P., MATUŠÍKOVÁ I. Variable responses of soybean chitinases to arsenic and cadmium stress at the whole plant level. Plant Growth Regulation 76 (2), 147, 2015.

22. MAGLOVSKI M., GERŠI Z., RYBANSKÝ L., BARDÁČOVÁ M., MORAVČÍKOVÁ J., BUJDOŠ M., DOBRIKOVA A., APOSTOLOVA E., KRAIC J., BLEHOVÁ A., MATUŠÍKOVÁ I. Effects of nutrition on wheat photosynthetic pigment responses to arsenic stress. Polish J. Environ. Sci. Studies, 28 (3), 1821, 2019.

23. CHANDRAKAR V., DUBEY A., KESHAVKANT S. Modulation of antioxidant enzymes by salicylic acid in arsenic exposed Glycine max L. J. Soil Sci. Plant Nutr. 16 (3), 662, 2016.

24. DHEER R., PATTERSON J., DUDASH M., STACHLER E.N., BIBBY K.J., STOLZ D.B., SHIVA S., WANG Z., HAZEN S.L., BARCHOWSKY A., STOLZ J.F. Arsenic induces structural and compositional colonic microbiome change and promotes host nitrogen and amino acid metabolism. Toxicol. Appl. Pharmacol. 289 (3), 397, 2015.

25. ISLAM M.K., KHANAM M.S., LEE S.Y., ALAM I., HUH M.R. The interaction of arsenic (As) and chromium
(Cr) influences growth and antioxidant status in tossa jute (Corchorus olitorius) P. O. J. 7 (6), 499, 2014.

26. BÉKÉSIOVÁ B., HRAŠKA S., LIBANTOVÁ J., MORAVČCÍKOVÁ J., MATUČÍKOVÁ I. Heavy-metal stress induced accumulation of chitinase isoforms in plants. Mol. Biol. Rep. 35 (4), 579, 2008.

27. PIRŠELOVÁ $\quad$ B., KUNA R., LIBANTOVÁ J., MORAVČÍKOVÁ J., MATUŠÍKOVÁ I. Biochemical and physiological comparison of heavy metal-triggered defense responses in the monocot maize and dicot soybean roots. Mol. Biol. Rep. 38, 3437, 2011.

28. O'LEXY, R., KASAI, K., CLARK, N., FUJIWARA, T., SOZZANI, R., GALLAGHER, K.L. Exposure to heavy metal stress triggers changes in plasmodesmatal permeability via deposition and breakdown of callose. J. Exp. Bot., 69 (15), 3715-3728, 2018.

29. MÉSZÁROS P., RYBANSKÝ L., HAUPTVOGEL P., KUNA R., LIBANTOVÁ J., MORAVČÍKOVÁ J., PIRŠELOVÁ B., TIRPÁKOVÁ A., MATUŠÍKOVÁ I. Cultivar-specific kinetics of chitinase induction in soybean roots during exposure to arsenic. Mol. Biol. Rep. 40 (3), 2127, 2013

30. GREGOROVÁ Z., KOVÁČIK J., KLEJDUS B., MAGLOVSKI M., KUNA R., HAUPTVOGEL P., MATUŠÍKOVÁ I. Drought-induced responses of physiology, metabolites, and $\mathrm{pr}$ proteins in Triticum aestivum. J. Agric. Food Chem. 63, 8125, 2015.

31. ZUR I., GOŁEBIOWSKA G., DUBAS E., GOLEMIEC E., MATUŠÍKOVÁ I., LIBANTOVÁ J., MORAVČÍKOVÁ J. $\beta$-1,3-glucanase and chitinase activities in winter triticales during cold hardening and subsequent infection by Microdochium nivale. Biologia 68, 241, 2013.

32. GROVER A. Plant chitinases: genetic diversity and physiological roles. Crit. Rev. Plant. Sci. 31 (1), 57, 2012.

33. XU X., FENG Y., FANG S., XU J., WANG X., GUO W. Genome-wide characterization of the $\beta$-1,3-glucanase gene family in Gossypium by comparative analysis. Sci. Rep. 6, 29044, 2016.

34. TAMARI Y., YAMAMOTO N., TSUJI H., KUSAKA Y. Thorium coprecipitation method for spectrophotometric determination of arsenic(III) and $\operatorname{arsenic}(\mathrm{V})$ in groundwaters. Anal. Sci. 5 (4), 481, 1989.

35. ADAMEC L. Leaf absorption of mineral nutrients in carnivorous plants stimulates root nutrient uptake. New Phytol. 155, 89, 2002.

36. GOJON A., GAYMARD F. Keeping nitrate in the roots: an unexpected requirement for cadmium tolerance in plants. J. Mol. Cell Biol. 2 (6), 299, 2010.

37. HURKMAN W.J., TANAKA C.K. Solubilization of plant membrane proteins for analysis by two-dimensional gel electrophoresis Plant Physiol. 81, 802, 1986.

38. MILLER G. Use of dinitrosalicylic acid reagent for determination of reducing sugar. Anal. Chem. 31, 426, 1959.

39. PAN S.Q., YE X.S., KUC J. A technique for detection of chitinase, beta-1,3-glucanase, and protein patterns after a single separation using polyacrylamide-gel electrophoresis or isolelectrofocusing. Phytopathology 81, 970, 1991.

40. ZEIER J. New insights into the regulation of plant immunity by amino acid metabolic pathways. Plant Cell Environ. 36, 2085, 2013.

41. ABBAS G., MURTAZA B., BIBI I., SHAHID M., NIAZI N.K., KHAN M.I., AMJAD M., HUSSAIN M. Arsenic uptake, toxicity, detoxification, and speciation in plants: physiological, biochemical, and molecular aspects. Int. J. Environ. Res. Public Health 15, 59, 2018. 
42. FINKEMEIER I., KLUGE C., METWALLY A., GEORGI M., GROTJOHANN N., DIETZ K.J. Alterations in Cdinduced gene expression under nitrogen deficiency in Hordeum vulgare. Plant Cell Environ. 26 (6), 821, 2003.

43. MISHRA S., MATTUSCH J., WENNRICH R. Accumulation and transformation of inorganic and organic arsenic in rice and role of thiol-complexation to restrict their translocation to shoot. Sci. Rep. 7, 40522, 2017.

44. GUSMAN G.S., OLIVEIRA J.A., FARNESE F.S., CAMBRAIA J. Arsenate and arsenite: the toxic effects on photosynthesis and growth of lettuce plants. Acta Physiol. Plant. 35, 1201, 2013.

45. RAHMAN M.A., HASEGAWA H., RAHMAN M.M., ISLAM M.N., MIAH M.A.M., TASMEN A. Effect of arsenic on photosynthesis, growth and yield of five widely cultivated rice (Oryza sativa L.) varieties in Bangladesh. Chemosphere 67, 1072, 2007.

46. LIN T., WAN X., ZHANG F. The short-term responses of glutathione and phytochelation synthetic pathways genes to additional nitrogen under cadmium stress in poplar leaves. Russ. J. Plant. Physiol. 63, 754, 2016.

47. HERNÁNDEZ L.E., SOBRINO-PLATA J., MONTEROPALMERO M.B., CARRASCO-GIL S., FLORESCÁCERES M.L., ORTEGA-VILLASANTE C., ESCOBAR C. Contribution of glutathione to the control of cellular redox homeostasis under toxic metal and metalloid stress. J. Exp. Bot. 66, 2901, 2015.

48. SRIVASTAVA S., PATHARE V.S., SOUNDERAJAN S., SUPRASANNA P., Nitrogen supply influences arsenic accumulation and stress responses of rice (Oryza sativa $\mathrm{L}$.) seedlings, J. Hazard. Mater. 367, 599, 2019.

49. KOVÁČIK J., HEDBAVNY J. Ammonium ions affect metal toxicity in chamomile plants, S. Afr. J. Bot. 94, 204, 2014.

50. WANG N.X., HUANG B., XU S., WEI Z.B., MIAO A.J., JI R., YANG L.Y. Effects of nitrogen and phosphorus on arsenite accumulation, oxidation, and toxicity in Chlamydomonas reinhardtii. Aquat. Toxicol. 157, 167, 2014.

51. MIAO A.J., WANG W.X. Predicting copper toxicity with its intracellular or subcellular concentration and the thiol synthesis in a marine diatom. Environ. Sci. Technol. 41, $1777,2007$.

52. SINGH N., MA L.Q., VU J.C., RAJ A. Effects of arsenic on nitrate metabolism in arsenic hyperaccumulating and non-hyperaccumulating ferns. Environ. Pollut. 157, 2300, 2009.

53. ATAFAR Z., MESDAGHINIA A., NOURI J., HOMAEE M., YUNESIAN M., AHMADIMOGHADDAM M., MAHVI A.H. Effect of fertilizer application on soil heavy metal concentration. Environ. Monit. Assess. 160, 83, 2010.

54. LANDBERG T., GREGER $\mathrm{M}$. Influence of $\mathrm{N}$ and $\mathrm{N}$ supplementation on $\mathrm{Cd}$ accumulation in wheat grain. Proceedings of the $7^{\text {th }}$ International Conference on the
Biochemistry of Trace Elements, Uppsala '03, Conference Proceedings 1: III, Swedish University of Agricultural Sciences, Uppsala, Sweden, 90, 2003.

55. ZHAO F.J., MCGRATH S.P, MEHARG A.A. Arsenic as a food chain contaminant: mechanisms of plant uptake and metabolism and mitigation strategies. In: Merchant S., Briggs W.R., Ort D. (eds.) Annu. Rev. Plant Biol. 61, Palo Alto, 535, 2010.

56. GUPTA P., SETH C.S. Nitrate supplementation attenuates $\mathrm{As}(\mathrm{V})$ toxicity in Solanum lycopersicum L. cv Pusa Rohini: Insights into $\mathrm{As}(\mathrm{V})$ sub-cellular distribution, photosynthesis, nitrogen assimilation, and DNA damage. Plant Physiol. Biochem. 139, 44, 2019.

57. PIGNA M., CAPORALE A.G., COZZOLINO V., FERNÁNDEZ LÓPEZ C., MORA M.L., SOMMELLA A., VIOLANTE A. Influence of phosphorus on the arsenic uptake by tomato (Solanum lycopersicum L.) irrigated with arsenic solutions at four different concentrations. J. Soil Sci. Plant Nutr. 12, 775, 2012.

58. MOKGALAKA-MATLALA N.S., FLORES-TAVIZÓN E., CASTILLO-MICHEL H., PERALTA-VIDEA JR., GARDEA-TORRESDEY J.L. Toxicity of arsenic (III) and (V) on plant growth, element uptake, and total amylolytic activity of mesquite (Prosopis Juliflora x P. Velutina). Int. J. Phytoremediat. 10 (1), 47, 2008.

59. DIJKSTRA J.A., HARRIS L.G., MELLO K., LITTERER A., WELLS C., WARE C. Invasive seaweeds transform habitat structure and increase biodiversity of associated species. J. Ecol. 105, 1668, 2017.

60. SUN Y., WANG M., MUR LAJ, SHEN Q., GUO S. Unravelling the roles of nitrogen nutrition in plant disease defences. Int. J. Mol. Sci. 21, 572, 2020.

61. SMAKOWSKA E., KONG J., BUSCH W., BELKHADIR Y. Organ specific regulation of growth-defense tradeoffs by plants. Curr. Opin. Plant Biol. 29, 129, 2016.

62. HUANG Y., CHEN H., REINFELDER J.R., LIANG X., SUN C., LIU C., LI F., YI J.A. Transcriptomic (RNA-seq) analysis of genes responsive to both cadmium and arsenic stress in rice root. Sci. Total Environ. 666, 445, 2019.

63. PIRŠELOVÁ, B., MISTRÍKOVÁ, V., LIBANTOVÁ, J., MORAVČÍKOVÁ J., MATUŠÍKOVÁ I. Study on metal-triggered callose deposition in roots of maize and soybean. Biologia 67, 698, 2012.

64. ZHANG F., WAN X., ZHONG Y. Nitrogen as an important detoxification factor to cadmium stress in poplar plants. J. Plant Interact. 9 (1), 249, 2014.

65. WANG Y.H, FENG Y., XU N.Y., CHEN B.L., MA R.H., ZHOU Z.G. Response of the enzymes to nitrogen applications in cotton fiber (Gossypium hirsutum L.) and their relationships with fiber strength. Sci. China C. Life Sci. 52,1065, 2009.

66. ZHU G., LI W., WANG G., LI L., SI Q., CAI C. GUO W. Genetic basis of fiber improvement and decreased stress tolerance in cultivated versus semi-domesticated upland cotton. Front. Plant Sci. 10, 1572, 2009. 


\section{Supplementary Material}

a)
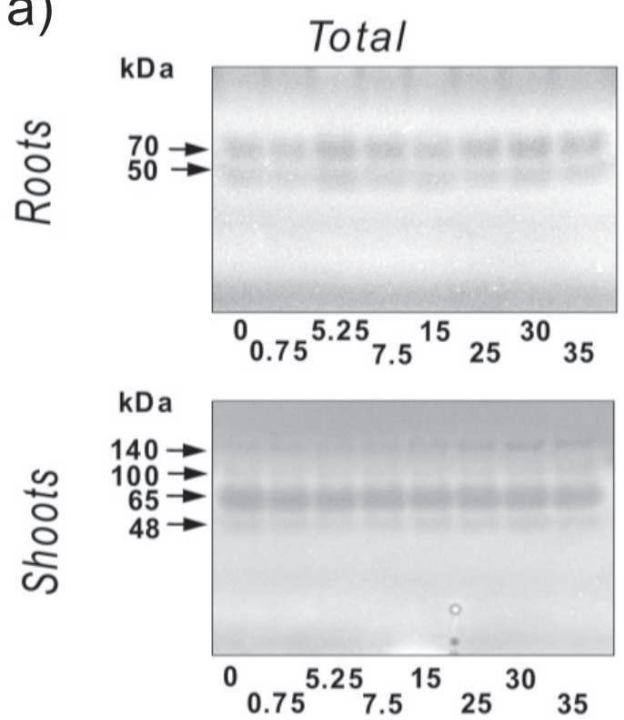

Chitinases
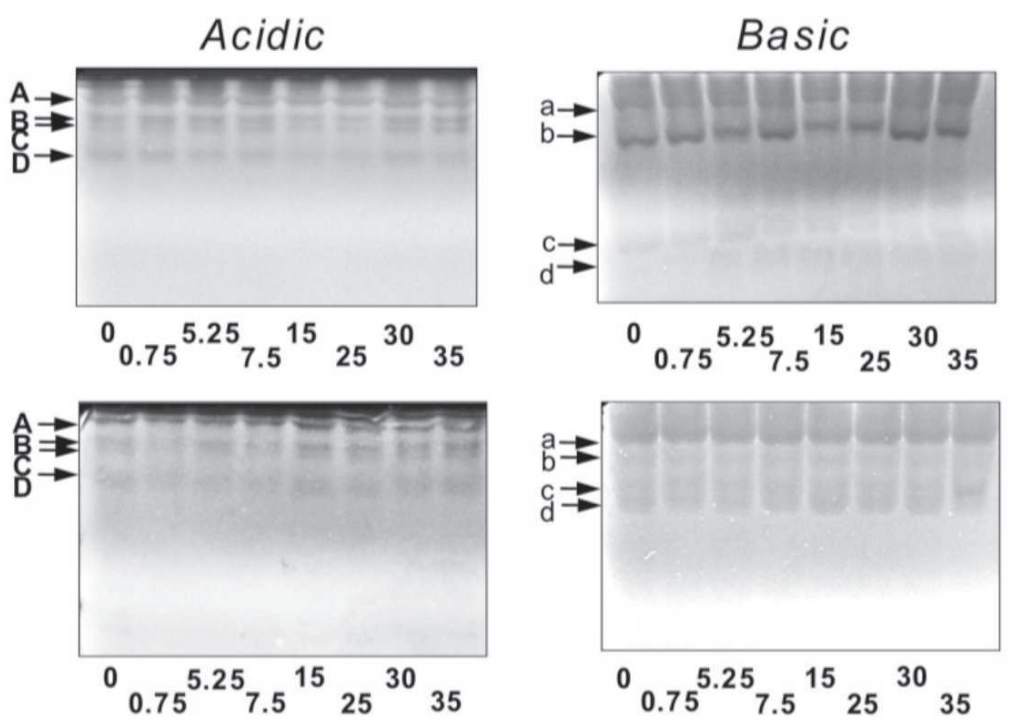

b)

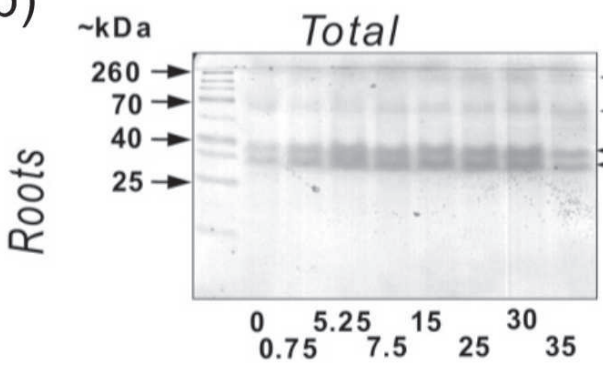

$\sim$ k Da

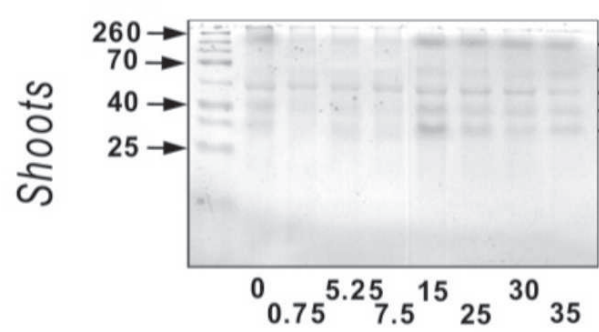

$\mathrm{N}$ concentration in media $(\mathrm{mM})$

\section{$\beta-1,3-G$ lucanases}
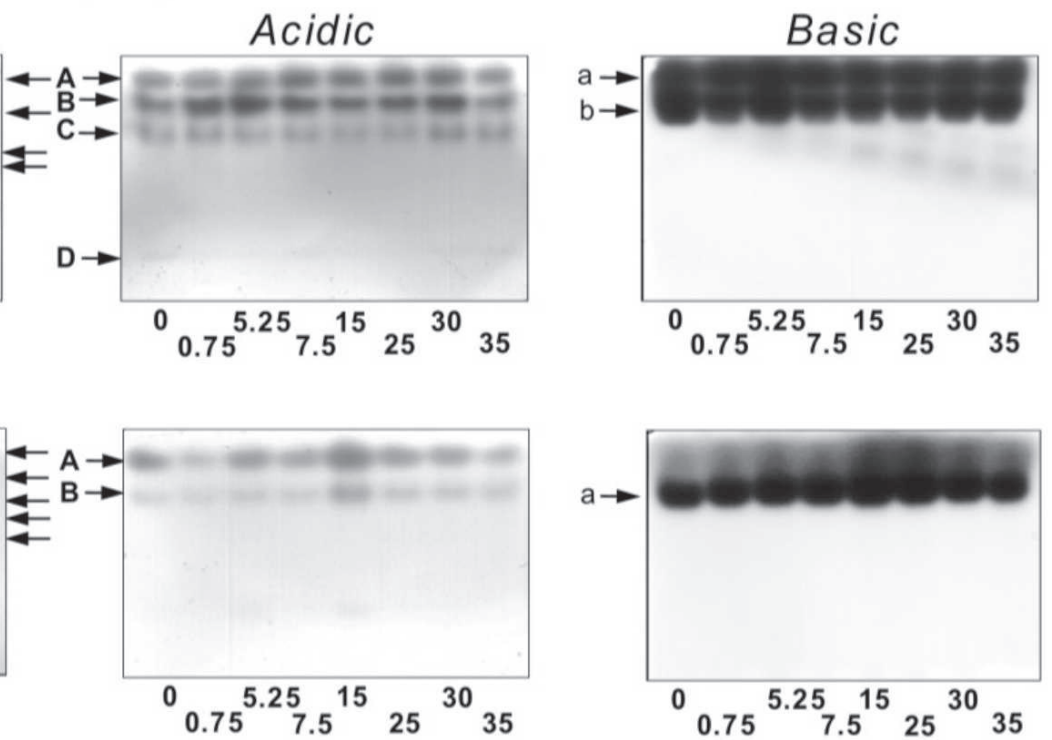

$\mathrm{N}$ concentration in media $(\mathrm{mM})$

Fig. S1. Isoforms of chitinases and $\beta$-1,3-glucanases from wheat roots and shoots grown at $5 \mathrm{mM} \mathrm{As} \mathrm{s}^{3+}$ and different concentrations of $\mathrm{NH}_{4} \mathrm{NO}_{3}$ in media (given below pictures, within 0-35 mM N). Reference samples were from plants without As (not shown). Detection in polyacrylamide gels was performed using specific enzyme substrates upon semi-denaturing conditions (separation of all isoforms by size; Total) or under native conditions (acidic/neutral or basic/neutral isoforms were separated). Size of enzyme fractions was determined on the basis of a co-separated molecular size marker. After scanning, the band intensities were determined using ScionImage software and the obtained values were statistically analysed for effect of $\mathrm{As}^{3+}, \mathrm{N}$ supply and both factors. 
Table S1. Overview of statistics on the influence of $\mathrm{As}^{3+}$, nitrogen supply and their interaction in wheat shoots and roots.

\begin{tabular}{|c|c|c|c|c|c|c|c|c|c|}
\hline \multirow{2}{*}{ Variable } & \multicolumn{3}{|c|}{ AsIII stress } & \multicolumn{3}{|c|}{$\mathrm{N}$ concentration } & \multicolumn{3}{|c|}{ Interaction of stress $\mathrm{x}$ concentration } \\
\hline & $F$ & $d f$ & $P$ & $F$ & $d f$ & $P$ & $F$ & $d f$ & $P$ \\
\hline \multicolumn{10}{|c|}{ Growth parameter } \\
\hline DW_root & 52,13 & 1 & $<0,001$ & 5,40 & 7 & 0,015 & 8,11 & 7 & 0,004 \\
\hline DW_shoot & 2,13 & 1 & 0,148 & 57,13 & 7 & $<0,001$ & 60,53 & 7 & $<0,001$ \\
\hline \multicolumn{10}{|c|}{ Content of elements } \\
\hline $\mathrm{N}$ content_shoot & 0,09 & 1 & 0,768 & 0,67 & 7 & 0,699 & 1,57 & 7 & 0,193 \\
\hline P content_shoot & 1,41 & 1 & 0,246 & 0,69 & 7 & 0,682 & 0,87 & 7 & 0,542 \\
\hline As content_shoot & 54,64 & 1 & $<0,001$ & 0,85 & 7 & 0,561 & 0,82 & 7 & 0,577 \\
\hline As content_root & 48,93 & 1 & $<0,001$ & 0,38 & 7 & 0,890 & 0,38 & 7 & 0,887 \\
\hline \multicolumn{10}{|l|}{ Total enzyme activities } \\
\hline Chitinases_root & 28,16 & 1 & $<0,001$ & 1,28 & 7 & 0,364 & 3,41 & 7 & 0,054 \\
\hline Chitinases_shoot & 10,52 & 1 & 0,002 & 6,65 & 7 & $<0,001$ & 6,21 & 7 & $<0,001$ \\
\hline$\beta-1,3$-Glucanase_root & 377,29 & 1 & $<0,001$ & 195,37 & 7 & 0,000 & 49,67 & 7 & $<0,001$ \\
\hline$\beta$-1,3-Glucanase_shoot & 28,53 & 1 & $<0,001$ & 6,57 & 7 & $<0,001$ & 3,91 & 7 & 0,001 \\
\hline \multicolumn{10}{|c|}{ Activities of chitinase isoforms } \\
\hline Chitinase_70 kDa_root & 12031,32 & 1 & $<0,001$ & 12,26 & 7 & 0,001 & 12,29 & 7 & 0,001 \\
\hline Chitinase_50 kDa_root & 38614,13 & 1 & $<0,001$ & 30,32 & 7 & $<0,001$ & 38,41 & 7 & $<0,001$ \\
\hline Acid chitinase_ $A$ _root & 28,83 & 1 & 0,001 & 1,38 & 7 & 0,328 & 0,32 & 7 & 0,922 \\
\hline Acid chitinase_B_root & 29,55 & 1 & 0,001 & 0,62 & 7 & 0,731 & 0,06 & 7 & 0,999 \\
\hline Acid chitinase_C_root & 90,92 & 1 & $<0,001$ & 1,34 & 7 & 0,343 & 0,57 & 7 & 0,761 \\
\hline Acid chitinase_D_root & 166,45 & 1 & $<0,001$ & 1,18 & 7 & 0,407 & 0,32 & 7 & 0,926 \\
\hline Basic chitinase_ $a$-root & 24,08 & 1 & 0,001 & 7,52 & 7 & 0,005 & 1,67 & 7 & 0,244 \\
\hline Basic chitinase_ $b$-root & 374,38 & 1 & $<0,001$ & 8,00 & 7 & 0,004 & 7,78 & 7 & 0,005 \\
\hline Chitinase_65 kDa_shoot & 28411,00 & 1 & $<0,001$ & 34,40 & 7 & $<0,001$ & 48,89 & 7 & $<0,001$ \\
\hline Chitinase_48 kDa_shoot & 2206,20 & 1 & $<0,001$ & 3,75 & 7 & 0,013 & 1,37 & 7 & 0,285 \\
\hline Chitinase_40 kDa_shoot & 2472,00 & 1 & $<0,001$ & 1,73 & 7 & 0,173 & 2,41 & 7 & 0,069 \\
\hline Chitinase_35 kDa_shoot & 1053,77 & 1 & $<0,001$ & 0,63 & 7 & 0,724 & 2,83 & 7 & 0,084 \\
\hline Acid chitinase_ $A$ _shoot & 123,47 & 1 & $<0,001$ & 0,73 & 7 & 0,645 & 1,71 & 7 & 0,135 \\
\hline Acid chitinase_B_shoot & 297,09 & 1 & $<0,001$ & 1,94 & 7 & 0,130 & 5,25 & 7 & 0,003 \\
\hline Acid chitinase_C_shoot & 284,16 & 1 & $<0,001$ & 2,00 & 7 & 0,119 & 3,66 & 7 & 0,015 \\
\hline Acid chitinase_D_shoot & 32,00 & 1 & $<0,001$ & 0,15 & 7 & 0,989 & 0,36 & 7 & 0,901 \\
\hline Basic chitinase_ $a \_$shoot & 2,44 & 1 & 0,128 & 1,37 & 7 & 0,250 & 2,19 & 7 & 0,062 \\
\hline Basic chitinase_b_shoot & 27,10 & 1 & 0,001 & 0,84 & 7 & 0,587 & 0,91 & 7 & 0,541 \\
\hline \multicolumn{10}{|c|}{ Activities of $\beta$-1,3-glucanase isoforms } \\
\hline$\beta$-1,3-Glucanase_150 kDa_root & 101,17 & 1 & $<0,001$ & 0,15 & 7 & 0,988 & 0,26 & 7 & 0,956 \\
\hline$\beta-1,3$-Glucanase_68 $\mathrm{kDa}$ _root & 125,13 & 1 & $<0,001$ & 5,16 & 7 & 0,017 & 7,17 & 7 & 0,006 \\
\hline$\beta-1,3$-Glucanase_45 $\mathrm{kDa}$ _root & 100,51 & 1 & $<0,001$ & 4,30 & 7 & 0,029 & 3,15 & 7 & 0,065 \\
\hline$\beta-1,3$-Glucanase_35 kDa_root & 409,73 & 1 & $<0,001$ & 4,12 & 7 & 0,032 & 5,70 & 7 & 0,013 \\
\hline Acid $\beta$-1,3-glucanase_A_root & 1,53 & 1 & 0,252 & 0,77 & 7 & 0,626 & 0,44 & 7 & 0,851 \\
\hline
\end{tabular}


Table S1. Continued.

\begin{tabular}{|c|c|c|c|c|c|c|c|c|c|}
\hline Acid $\beta-1,3$-glucanase_ $B$ _root & 0,63 & 1 & 0,452 & 1,65 & 7 & 0,250 & 0,64 & 7 & 0,715 \\
\hline Acid $\beta$-1,3-glucanase_C_root & 18,79 & 1 & 0,002 & 0,38 & 7 & 0,893 & 3,01 & 7 & 0,073 \\
\hline Basic $\beta$-1,3-glucanase_a_root & 91,98 & 1 & $<0,001$ & 4,51 & 7 & 0,025 & 10,32 & 7 & 0,002 \\
\hline Basic $\beta$-1,3-glucanase_ $b$ _root & 42,28 & 1 & $<0,001$ & 3,93 & 7 & 0,037 & 6,57 & 7 & 0,008 \\
\hline$\beta-1,3$-Glucanase_150 kDa_shoot & 0,69 & 1 & 0,415 & 6,52 & 7 & $<0,001$ & 8,15 & 7 & $<0,001$ \\
\hline$\beta$-1,3-Glucanase_68 kDa_shoot & 1,96 & 1 & 0,180 & 1,27 & 7 & 0,327 & 0,44 & 7 & 0,861 \\
\hline$\beta$-1,3-Glucanase_50 kDa_shoot & 1098,58 & 1 & $<0,001$ & 2,23 & 7 & 0,088 & 1,29 & 7 & 0,317 \\
\hline$\beta$-1,3-Glucanase_38 kDa_shoot & 56,71 & 1 & $<0,001$ & 1,04 & 7 & 0,474 & 0,90 & 7 & 0,550 \\
\hline$\beta$-1,3-Glucanase_30 kDa_shoot & 20,33 & 1 & 0,002 & 8,26 & 7 & 0,004 & 10,67 & 7 & 0,002 \\
\hline Acid $\beta$-1,3-glucanase_ $A$ _shoot & 119,45 & 1 & $<0,001$ & 6,69 & 7 & $<0,001$ & 8,90 & 7 & $<0,001$ \\
\hline Acid $\beta$-1,3-glucanase_ $A$ _shoot & 177,45 & 1 & $<0,001$ & 1,76 & 7 & 0,165 & 4,08 & 7 & 0,009 \\
\hline Basic $\beta$-1,3-glucanase_a_shoot & 7,52 & 1 & 0,010 & 2,78 & 7 & 0,022 & 0,69 & 7 & 0,677 \\
\hline
\end{tabular}

$F$ - F value

$d f$ - degree of freedom

$P$ - significance 


\begin{tabular}{|c|c|c|c|c|c|c|c|c|c|c|c|c|c|c|c|c|c|c|c|c|c|c|c|c|c|c|}
\hline $\mid$\begin{tabular}{|l}
$Z$ \\
$z$ \\
$\Xi$ \\
$w$ \\
$m$
\end{tabular} & 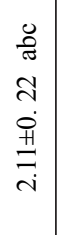 & \begin{tabular}{|l|}
$\pi$ \\
0 \\
0 \\
0 \\
0 \\
+1 \\
\multirow{H}{*}{} \\
0 \\
0
\end{tabular} & 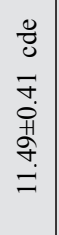 & 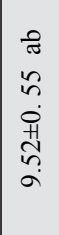 & & $\begin{array}{l}0 \\
\sim \\
\dot{0} \\
\dot{0} \\
\tilde{n} \\
\dot{r}\end{array}$ & $\begin{array}{l}\pi \\
\simeq \\
\simeq \\
0 \\
0 \\
0 \\
e \\
\dot{+}\end{array}$ & $\begin{array}{l}0 \\
0 \\
0 \\
0 \\
+1 \\
0 \\
0 \\
0\end{array}$ & $\mid \begin{array}{l}0 \\
\tilde{\sigma} \\
0 \\
0 \\
0 \\
0 \\
\infty \\
0 \\
0\end{array}$ & 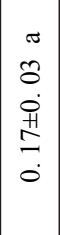 & $\begin{array}{l}0 \\
\infty \\
\infty \\
o \\
\stackrel{\vec{H}}{+} \\
\stackrel{1}{ \pm} \\
\dot{\vec{j}}\end{array}$ & $\begin{array}{l}\sigma \\
8 \\
8 \\
0 \\
+1 \\
0 \\
0 \\
0\end{array}$ & 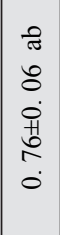 & & 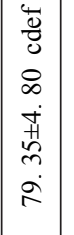 & 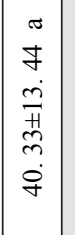 & 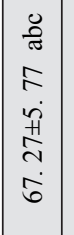 & 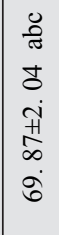 & $\mid \begin{array}{c}\sigma \\
0 \\
0 \\
\dot{H} \\
\tilde{N} \\
\dot{m}\end{array}$ & 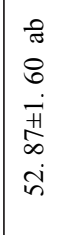 & 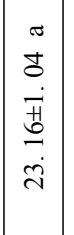 & $\mid$\begin{tabular}{c|}
0 \\
0 \\
0 \\
$\dot{H}$ \\
$\tilde{N}$ \\
$\dot{\gamma}$ \\
$\dot{f}$
\end{tabular} & $\left|\begin{array}{c}\sigma \\
\infty \\
\dot{H} \\
\sigma \\
\dot{n} \\
\Xi\end{array}\right|$ & 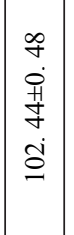 & & $\begin{array}{l}\text { के } \\
\text { in } \\
\text { के } \\
\text { मे } \\
\text { षे }\end{array}$ \\
\hline $\mid$\begin{tabular}{|l}
$Z$ \\
$\sum$ \\
$\Xi$ \\
$D$ \\
$e$
\end{tabular} & $\begin{array}{c}0 \\
\tilde{n} \\
\stackrel{0}{0} \\
\stackrel{H}{\Rightarrow} \\
\dot{m}\end{array}$ & \begin{tabular}{|l|}
$\sigma$ \\
$o$ \\
$o$ \\
$\dot{1}$ \\
$\tilde{1}$ \\
$\tilde{\sigma}$ \\
$\dot{0}$
\end{tabular} & $\begin{array}{l}\tilde{\theta} \\
\tilde{m} \\
\dot{0} \\
\dot{\theta} \\
= \\
\dot{m}\end{array}$ & $\begin{array}{l}\frac{0}{\pi} \\
\hat{n} \\
\dot{0} \\
\dot{0} \\
\dot{\sigma} \\
\sigma \\
\sigma\end{array}$ & & $\begin{array}{l}\overrightarrow{\tilde{\sigma}} \\
\tilde{o} \\
\dot{+} \\
\dot{H} \\
\overrightarrow{+} \\
\dot{\sigma}\end{array}$ & 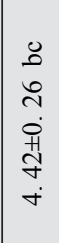 & $\begin{array}{l}0 \\
\overrightarrow{0} \\
\dot{0} \\
+ \\
\infty \\
\dot{0}\end{array}$ & $\mid \begin{array}{l}0 \\
0 \\
0 \\
0 \\
0 \\
0 \\
\infty \\
0 \\
0\end{array}$ & $\begin{array}{l}\sigma \\
0 \\
0 \\
0 \\
0 \\
0 \\
0 \\
0\end{array}$ & 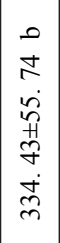 & $\begin{array}{l}\sigma \\
8 \\
8 \\
0 \\
+1 \\
0 \\
0 \\
0\end{array}$ & 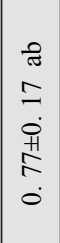 & & 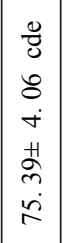 & \begin{tabular}{|c|}
$\vec{D}$ \\
$\dot{0}$ \\
$\infty$ \\
$\infty$ \\
$\dot{D}$ \\
$\dot{H}$ \\
$\dot{b}$ \\
$\dot{F}$ \\
$\dot{F}$
\end{tabular} & 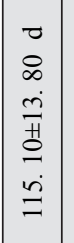 & $\begin{array}{l}\approx \\
= \\
\dot{+} \\
\ddot{\partial} \\
0 \\
\dot{J}\end{array}$ & 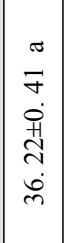 & 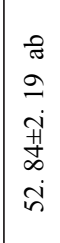 & \begin{tabular}{|c|}
0 \\
0 \\
0 \\
0 \\
0 \\
0 \\
+ \\
$\dot{n}$
\end{tabular} \mid & $\begin{array}{c}0 \\
\vec{n} \\
0 \\
0 \\
0 \\
\dot{y} \\
\dot{v}\end{array}$ & $\mid \begin{array}{l}\partial \\
\dot{\vec{H}} \\
\dot{0} \\
\dot{\partial} \\
\partial\end{array}$ & $\left|\begin{array}{c} \pm \\
\dot{J} \\
\dot{H} \\
0 \\
\dot{0} \\
0\end{array}\right|$ & 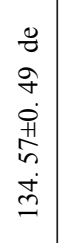 & 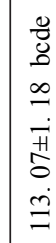 \\
\hline 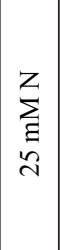 & 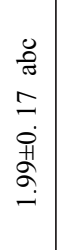 & $\mid \begin{array}{c}0 \\
\tilde{\pi} \\
0 \\
0 \\
0 \\
0 \\
\hat{1} \\
\hat{\sigma} \\
0 \\
0\end{array}$ & 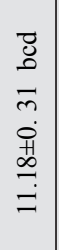 & $\begin{array}{l}0 \\
0 \\
\tilde{n} \\
\hat{2} \\
01 \\
\hat{n} \\
\hat{2} \\
0\end{array}$ & & $\begin{array}{c}0 \\
\tilde{m} \\
\stackrel{0}{0} \\
\stackrel{1}{\infty} \\
\stackrel{0}{*} \\
\dot{\sigma}\end{array}$ & $\begin{array}{c}0 \\
0 \\
0 \\
0 \\
0 \\
0 \\
0 \\
0 \\
+ \\
\dot{0}\end{array}$ & 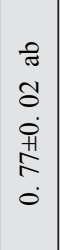 & $\begin{array}{l}0 \\
0 \\
0 \\
0 \\
0 \\
0 \\
0 \\
0\end{array}$ & $\begin{array}{l}\sigma \\
0 \\
0 \\
0 \\
0 \\
\infty \\
0 \\
0 \\
0\end{array}$ & 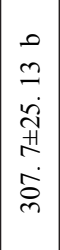 & $\begin{array}{l}0 \\
8 \\
0 \\
0 \\
+1 \\
0 \\
0\end{array}$ & $\begin{array}{l}0 \\
\pi \\
0 \\
0 \\
0 \\
0 \\
0 \\
6 \\
0 \\
0\end{array}$ & & $\begin{array}{c}0 \\
\tilde{\sigma} \\
\infty \\
\infty \\
\dot{0} \\
\dot{H} \\
\overrightarrow{1} \\
\dot{\infty}\end{array}$ & 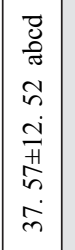 & 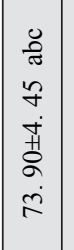 & 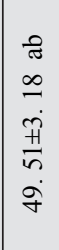 & \begin{tabular}{c|c}
$\sigma$ \\
0 \\
0 \\
0 \\
0 \\
$\infty$ \\
$+\dot{D}$ \\
$\dot{D}$
\end{tabular} & 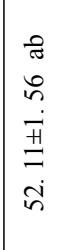 & 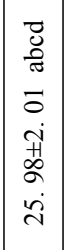 & 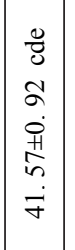 & $\left|\begin{array}{l}\infty \\
0 \\
0 \\
0 \\
n \\
0 \\
\ddot{n} \\
=\end{array}\right|$ & $\begin{array}{c}z \\
\dot{\vec{H}} \\
\dot{H} \\
\dot{v} \\
\dot{0}\end{array}$ & 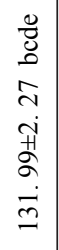 & $\begin{array}{l}\overrightarrow{0} \\
0 \\
\tilde{\sigma} \\
0 \\
\dot{0} \\
\dot{0} \\
i \\
\dot{J} \\
\dot{J}\end{array}$ \\
\hline \begin{tabular}{|c}
$z$ \\
$\sum_{a}$ \\
$n$ \\
$n$
\end{tabular} & 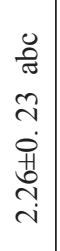 & 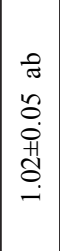 & 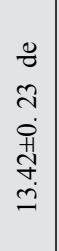 & 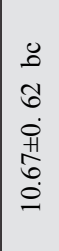 & & $\begin{array}{c}0 \\
\dot{8} \\
0 \\
\dot{1} \\
\ddot{0} \\
\dot{+} \\
\dot{+}\end{array}$ & 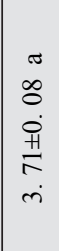 & $\begin{array}{l}0 \\
0 \\
\tilde{d} \\
\dot{0} \\
\dot{0} \\
\infty \\
0 \\
\dot{0}\end{array}$ & $\begin{array}{l}\sigma \\
\sigma \\
0 \\
0 \\
0 \\
+1 \\
0 \\
0 \\
0\end{array}$ & $\begin{array}{c}0 \\
\tilde{a} \\
\tilde{a} \\
\dot{0} \\
\dot{1} \\
0 \\
\dot{0}\end{array}$ & 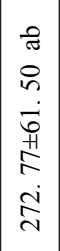 & $\begin{array}{l}\sigma \\
8 \\
0 \\
0 \\
\ddot{1} \\
0 \\
0 \\
\dot{0}\end{array}$ & $\begin{array}{l}0 \\
0 \\
0 \\
0 \\
0 \\
0 \\
0 \\
-1\end{array}$ & & 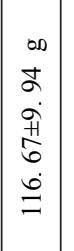 & 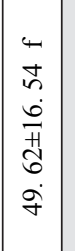 & 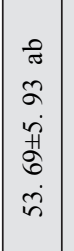 & 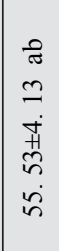 & $\begin{array}{l}\sigma \\
\tilde{b} \\
0 \\
0 \\
0 \\
0 \\
0 \\
\dot{n}\end{array}$ & 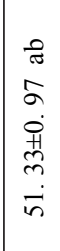 & 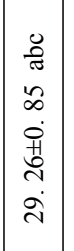 & 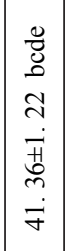 & $\left|\begin{array}{c}\infty \\
\dot{H} \\
\dot{H} \\
0 \\
\dot{0} \\
0\end{array}\right|$ & 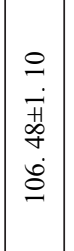 & 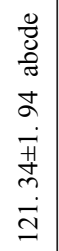 & 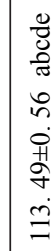 \\
\hline $\begin{array}{c}z \\
\sum \\
g \\
n \\
n \\
r\end{array}$ & $\begin{array}{l}0 \\
0 \\
\infty \\
\stackrel{0}{0} \\
\ddot{H} \\
\tilde{i} \\
\end{array}$ & \begin{tabular}{|c|}
0 \\
$\tilde{\pi}$ \\
0 \\
$\dot{0}$ \\
$\dot{0}$ \\
$\dot{0}$ \\
-1 \\
\end{tabular} & $\begin{array}{c}0 \\
\tilde{m} \\
0 \\
0 \\
0 \\
\infty \\
\stackrel{n}{0}\end{array}$ & $\begin{array}{l}0 \\
0 \\
0 \\
0 \\
0 \\
0 \\
\infty \\
= \\
=\end{array}$ & 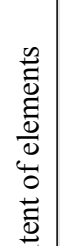 & $\begin{array}{l}0 \\
= \\
= \\
\dot{0} \\
\dot{+} \\
\dot{r} \\
\dot{r}\end{array}$ & 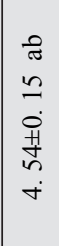 & $\begin{array}{l}\tilde{\pi} \\
\tilde{b} \\
\dot{0} \\
\ddot{0} \\
\tilde{0} \\
\dot{0}\end{array}$ & $\begin{array}{l}0 \\
0 \\
0 \\
0 \\
0 \\
+1 \\
\infty \\
0 \\
0\end{array}$ & $\begin{array}{l}\sigma \\
\sigma \\
o \\
\dot{0} \\
\dot{+} \\
\vec{\lambda} \\
\dot{0}\end{array}$ & 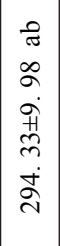 & $\begin{array}{l}\sigma \\
8 \\
0 \\
\dot{0} \\
\tilde{1} \\
0 \\
\dot{0}\end{array}$ & 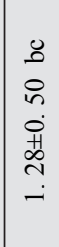 & 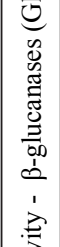 & 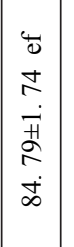 & 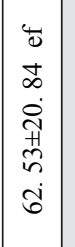 & $\mid \begin{array}{c}0 \\
\tilde{0} \\
0 \\
0 \\
\dot{+} \\
\dot{+} \\
0 \\
\dot{0} \\
\dot{0}\end{array}$ & 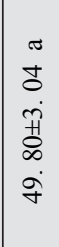 & $\begin{array}{l}0 \\
\infty \\
0 \\
0 \\
0 \\
0 \\
0 \\
\dot{m}\end{array}$ & 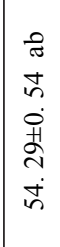 & \begin{tabular}{|l|}
$\vec{z}$ \\
0 \\
0 \\
0 \\
0 \\
0 \\
0 \\
0 \\
$\infty$ \\
$\infty$ \\
$\infty$
\end{tabular} & $\left|\begin{array}{l}0 \\
n \\
n \\
0 \\
0 \\
i n \\
\dot{y} \\
q\end{array}\right|$ & 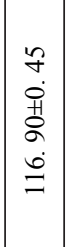 & $\left|\begin{array}{l}\tilde{2} \\
0 \\
0+1 \\
0 \\
0 \\
0 \\
0\end{array}\right|$ & 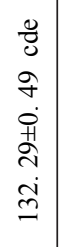 & 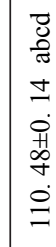 \\
\hline 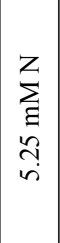 & $\begin{array}{c}0 \\
= \\
\dot{0} \\
+ \\
\hat{0} \\
\dot{i}\end{array}$ & \begin{tabular}{|c|}
$\frac{0}{\pi}$ \\
0 \\
0 \\
$\dot{0}$ \\
$\dot{+}$ \\
0 \\
- \\
-1
\end{tabular} & $\begin{array}{l}0 \\
0 \\
q \\
\dot{1} \\
\dot{m} \\
m \\
\tilde{m}\end{array}$ & 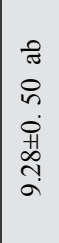 & 0 & 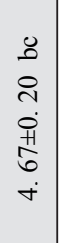 & $\begin{array}{l}\sigma \\
\pm \\
\pm \\
0 \\
0 \\
0 \\
\dot{\theta} \\
\dot{\theta}\end{array}$ & $\begin{array}{l}\approx \\
\tilde{\pi} \\
0 \\
\dot{0} \\
\dot{0} \\
\stackrel{0}{0} \\
\dot{0}\end{array}$ & $\begin{array}{l}0 \\
0 \\
\tilde{0} \\
0 \\
0 \\
0 \\
0 \\
0 \\
0\end{array}$ & 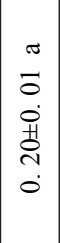 & $\begin{array}{l}0 \\
0 \\
8 \\
\dot{J} \\
\dot{+} \\
\infty \\
\dot{0} \\
\dot{n} \\
m\end{array}$ & $\begin{array}{l}\sigma \\
8 \\
8 \\
0 \\
\ddot{1} \\
\tilde{1} \\
0 \\
0\end{array}$ & 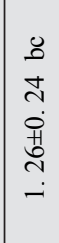 & 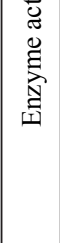 & 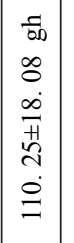 & 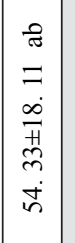 & $\begin{array}{c}0 \\
\tilde{\sigma} \\
\infty \\
\infty \\
i \\
\tilde{d} \\
\tilde{d} \\
\dot{\vec{n}} \\
\hat{n}\end{array}$ & 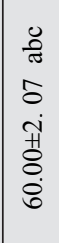 & 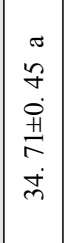 & 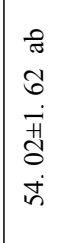 & $\begin{array}{c}0 \\
\tilde{\sigma} \\
0 \\
0 \\
0 \\
0 \\
+1 \\
0 \\
0 \\
\sim\end{array} \mid$ & $\begin{array}{c}0 \\
0 \\
0 \\
0 \\
0 \\
0 \\
0 \\
0 \\
+ \\
f \\
\dot{\sigma}\end{array} \mid$ & $\begin{array}{l}0 \\
i \\
i \\
+ \\
\infty \\
2 \\
\Xi \\
=\end{array}$ & $\left|\begin{array}{c}0 \\
n \\
i \\
\dot{H} \\
0 \\
\dot{0} \\
0\end{array}\right|$ & 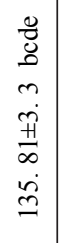 & 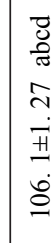 \\
\hline $\mid \begin{array}{c}z \\
\sum \\
\Xi \\
\vdots \\
\hat{\sigma} \\
\vdots\end{array}$ & 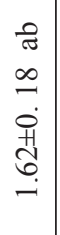 & $\begin{array}{c}0 \\
\tilde{\sigma} \\
0 \\
0 \\
0 \\
0 \\
0 \\
0 \\
-1 \\
-1\end{array}$ & 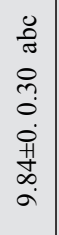 & $\begin{array}{l}0 \\
0 \\
n \\
m \\
0 \\
0 \\
0 \\
0 \\
0 \\
0\end{array}$ & & 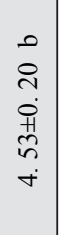 & $\begin{array}{l}\text { बे } \\
\text { ते } \\
0 \\
0 \\
0 \\
0 \\
\dot{+}\end{array}$ & $\begin{array}{l}\approx \\
\tilde{\pi} \\
8 \\
\dot{0} \\
\stackrel{0}{0} \\
\dot{0}\end{array}$ & $\begin{array}{l}0 \\
0 \\
2 \\
0 \\
0 \\
0 \\
\stackrel{1}{1} \\
0 \\
0\end{array}$ & 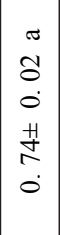 & $\begin{array}{l}0 \\
\tilde{\sigma} \\
\vec{n} \\
\infty \\
\tilde{1} \\
\overrightarrow{0} \\
0 \\
\vec{j} \\
\vec{\sim}\end{array}$ & $\begin{array}{l}\sigma \\
0 \\
0 \\
0 \\
+1 \\
0 \\
0\end{array}$ & $\begin{array}{l}0 \\
0 \\
\hat{~} \\
0 \\
0 \\
0 \\
\infty \\
\infty \\
0\end{array}$ & & 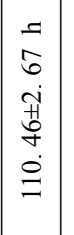 & 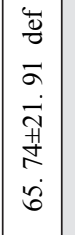 & 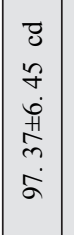 & 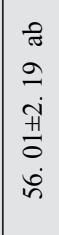 & 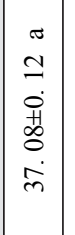 & $\begin{array}{l}\sigma \\
n \\
\dot{\vec{H}} \\
\tilde{y} \\
\dot{n}\end{array}$ & 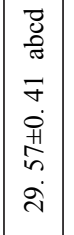 & $\left|\begin{array}{l|}0 \\
0 \\
0 \\
0 \\
0 \\
\infty \\
0 \\
0 \\
0 \\
0 \\
\infty \\
\infty \\
0\end{array}\right|$ & 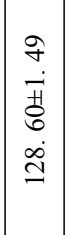 & 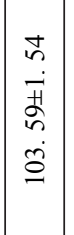 & $\begin{array}{l}0 \\
\tilde{m} \\
\dot{\vec{H}} \\
\stackrel{+}{ \pm} \\
\dot{ \pm}\end{array}$ & 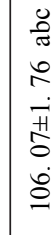 \\
\hline $\begin{array}{l}Z \\
\sum_{g} \\
\Xi \\
\end{array}$ & 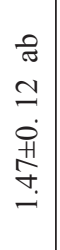 & 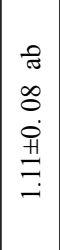 & $\begin{array}{l}\frac{\sigma}{\vec{m}} \\
\stackrel{\overrightarrow{0}}{0} \\
\underset{+}{+} \\
\dot{\infty}\end{array}$ & $\begin{array}{c}\sigma \\
\vec{m} \\
\dot{0} \\
0 \\
0 \\
\infty \\
\infty\end{array}$ & & $\begin{array}{l}\tilde{\sigma} \\
\hat{0} \\
\dot{0} \\
\dot{0} \\
0 \\
\dot{\sigma}\end{array}$ & 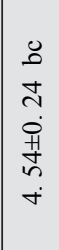 & $\begin{array}{l}\text { क } \\
\dot{0} \\
\dot{0} \\
\dot{0} \\
\\
\vdots \\
0\end{array}$ & $\begin{array}{l}0 \\
0 \\
0 \\
0 \\
0 \\
+1 \\
0 \\
0\end{array}$ & $\begin{array}{l}0 \\
0 \\
0 \\
0 \\
0 \\
0 \\
0 \\
0 \\
0\end{array}$ & 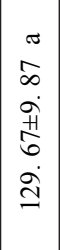 & $\begin{array}{l}0 \\
8 \\
0 \\
0 \\
0 \\
0 \\
0\end{array}$ & $\begin{array}{l}\approx \\
0 \\
\dot{0} \\
\dot{11} \\
\text { के } \\
0\end{array}$ & & 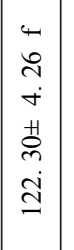 & 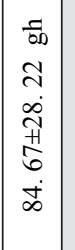 & 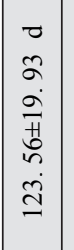 & 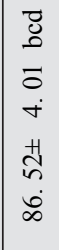 & 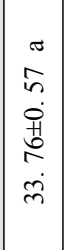 & 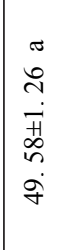 & 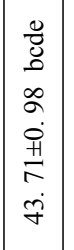 & 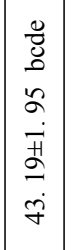 & 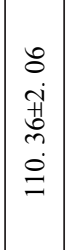 & $\mid \begin{array}{l}\infty \\
0 \\
0 \\
01 \\
0 \\
0 \\
\vdots \\
0\end{array}$ & 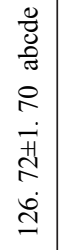 & 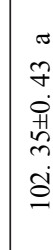 \\
\hline & $\sum_{1}^{\infty}$ & $\begin{array}{l}2 \\
\vdots \\
+\end{array}$ & $\sum_{1}^{2}$ & \begin{tabular}{l}
2 \\
\multirow{2}{*}{} \\
+
\end{tabular} & & $\sum_{1}^{\infty}$ & \begin{tabular}{l}
2 \\
\multirow{4}{*}{} \\
+
\end{tabular} & $\underset{1}{2}$ & \begin{tabular}{l}
$y$ \\
\multirow{1}{x}{} \\
+
\end{tabular} & $\sum_{1}^{\infty}$ & $\begin{array}{l}n \\
2 \\
+\end{array}$ & $\sum_{1}^{\infty}$ & $\begin{array}{l}\sum_{4}^{2} \\
+\end{array}$ & & $\begin{array}{l}2 \\
1 \\
1\end{array}$ & $\begin{array}{l}2 \\
2 \\
+\end{array}$ & $\sum_{1}^{\infty}$ & \begin{tabular}{l}
2 \\
\multirow{4}{4}{} \\
+
\end{tabular} & $\sum_{1}^{n}$ & \begin{tabular}{l}
$n$ \\
\multirow{1}{*}{} \\
+
\end{tabular} & $\begin{array}{l}2 \\
4 \\
1\end{array}$ & $\left|\begin{array}{l}2 \\
2 \\
+\end{array}\right|$ & $\begin{array}{l}0 \\
4 \\
1\end{array}$ & $\sum_{+}^{2}$ & $\sum_{1}^{\infty}$ & $\underset{t}{2}$ \\
\hline & $\simeq$ & $\simeq$ & $n$ & is & & $n$ & in & $\infty$ & is & $\simeq$ & $\simeq$ & os & is & & $\simeq$ & $\simeq$ & is & is & $\simeq$ & $\simeq$ & $\simeq$ & $\simeq$ & $\simeq$ & $\simeq$ & $\simeq$ & $\simeq$ \\
\hline 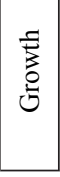 & \multicolumn{2}{|c|}{ 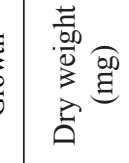 } & \multicolumn{2}{|c|}{ 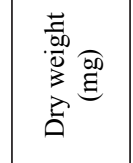 } & \multicolumn{3}{|c|}{ 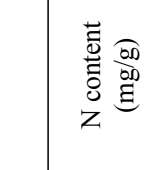 } & \multicolumn{2}{|c|}{ 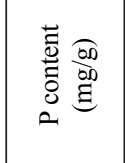 } & \multicolumn{2}{|c|}{ 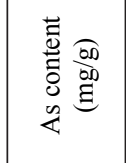 } & \multicolumn{2}{|c|}{ 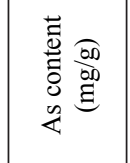 } & \multicolumn{3}{|c|}{ 竎 } & \multicolumn{2}{|c|}{ 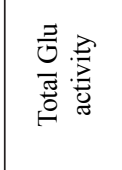 } & \multicolumn{2}{|c|}{$\begin{array}{l}\tilde{a} \\
\frac{0}{0} \\
\frac{n}{1} \\
\frac{1}{0}\end{array}$} & \multicolumn{2}{|c|}{ 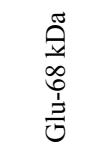 } & & \multicolumn{2}{|c|}{$\begin{array}{l}\tilde{O} \\
\frac{O}{n} \\
? \\
\tilde{J}\end{array}$} \\
\hline
\end{tabular}




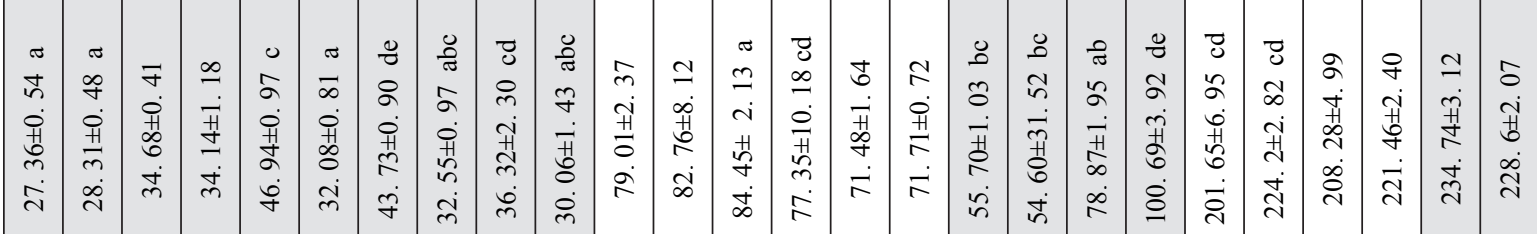

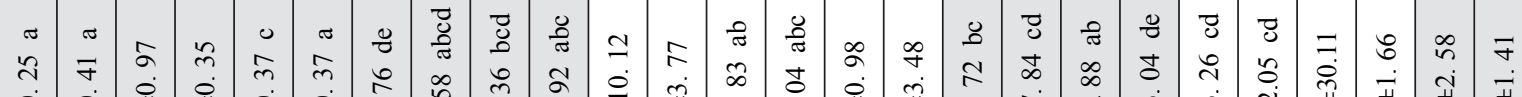

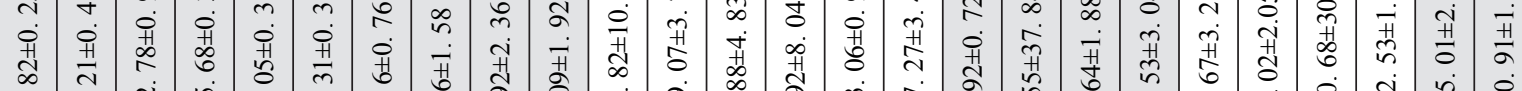

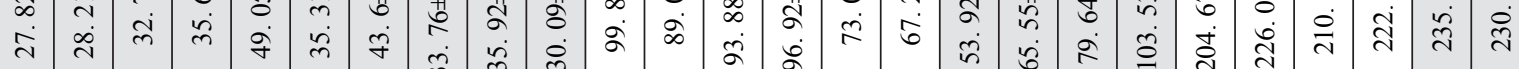

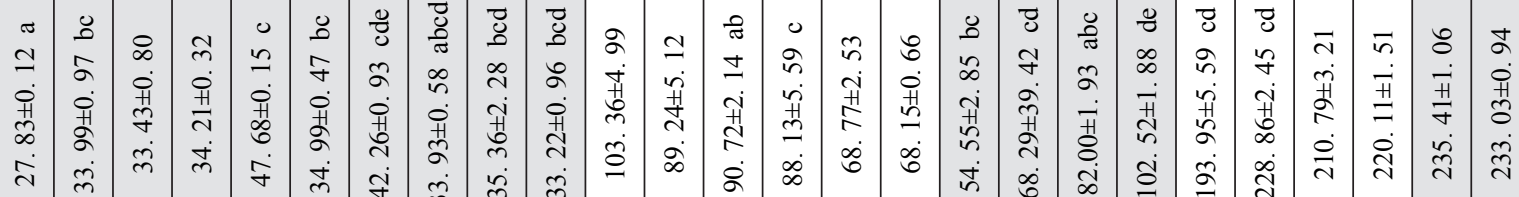

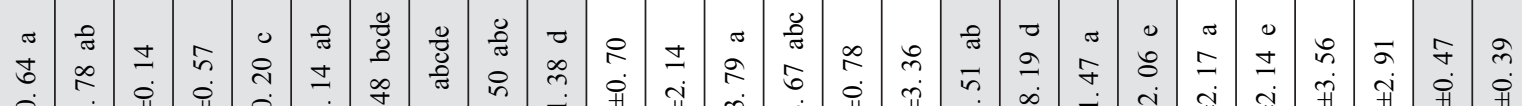

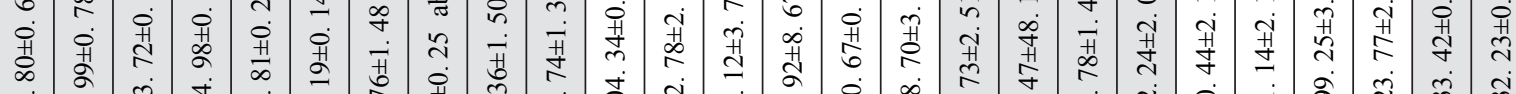

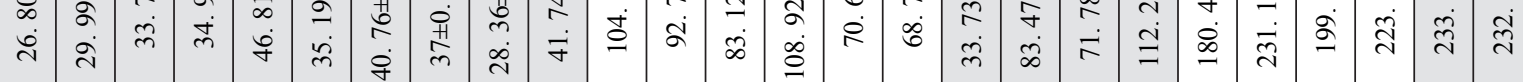

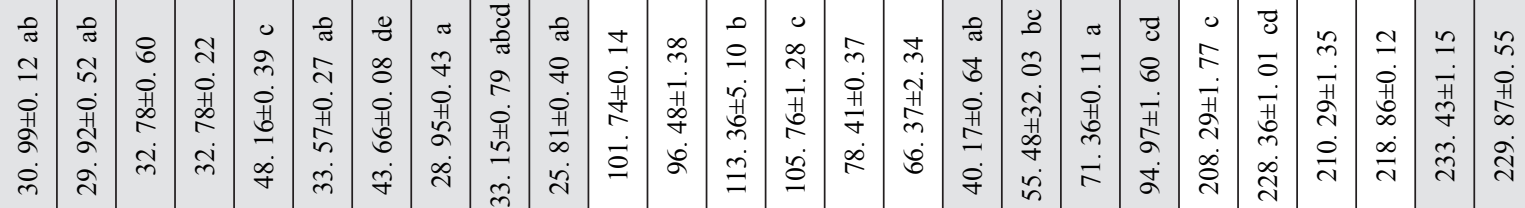

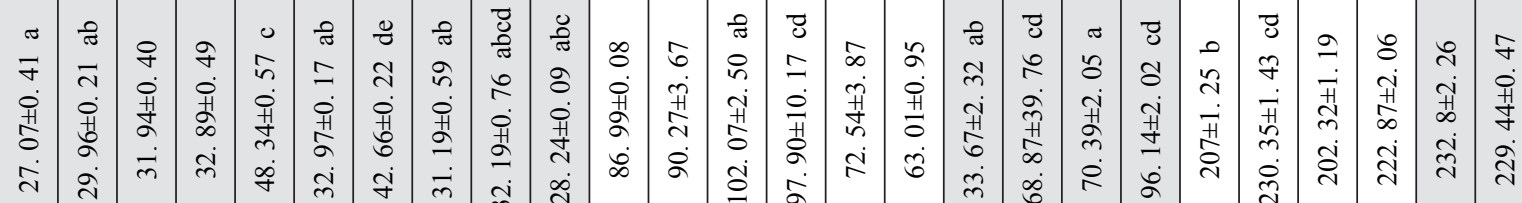

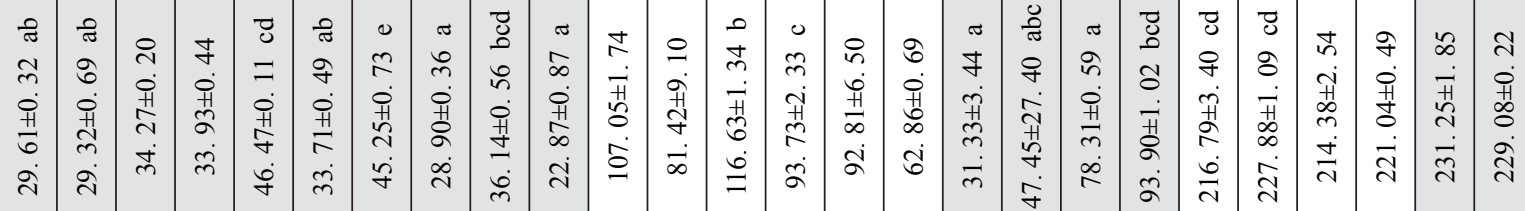

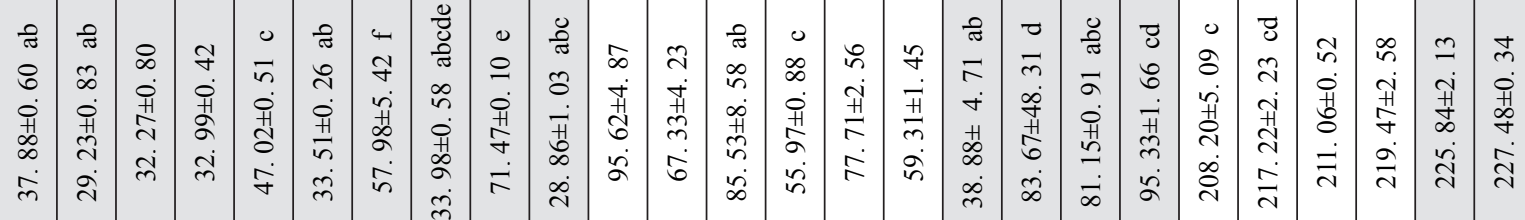

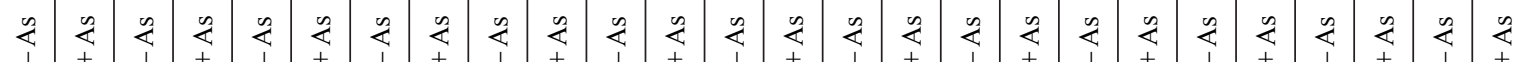

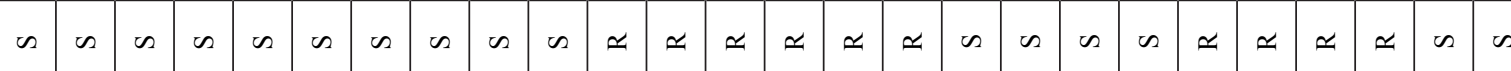

\begin{tabular}{|c|c|c|c|c|c|c|c|c|c|c|c|}
\hline $\begin{array}{l}\frac{\tilde{O}}{0} \\
\frac{n}{n} \\
\frac{1}{\tilde{J}}\end{array}$ & 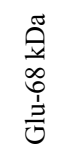 & $\begin{array}{l}\tilde{O} \\
\frac{0}{0} \\
0 \\
\frac{1}{3} \\
0\end{array}$ & $\begin{array}{l}\tilde{D} \\
\stackrel{\Xi}{0} \\
\infty \\
\stackrel{1}{0} \\
0\end{array}$ & 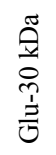 & 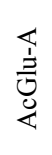 & 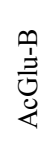 & 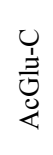 & $\begin{array}{l}\mathbb{1} \\
\frac{1}{\bar{y}} \\
\text { }\end{array}$ & 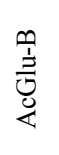 & 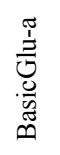 & 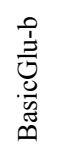 \\
\hline
\end{tabular}




\begin{tabular}{|c|c|c|c|c|c|c|c|c|c|c|c|c|c|c|c|c|c|c|c|c|c|c|c|c|c|c|}
\hline & 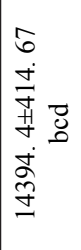 & $\begin{array}{l}0 \\
0 \\
0 \\
0 \\
0 \\
0 \\
0 \\
0 \\
\dot{0} \\
\dot{\infty} \\
0 \\
n\end{array}$ & 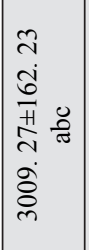 & 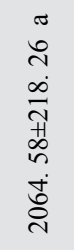 & 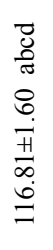 & 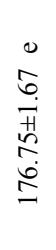 & 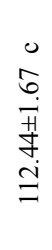 & 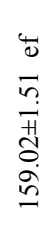 & 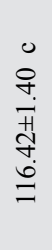 & $\begin{array}{l}0 \\
\infty \\
0 \\
0 \\
0 \\
0 \\
0 \\
0\end{array}$ & 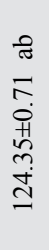 & 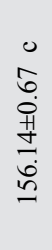 & 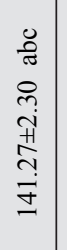 & 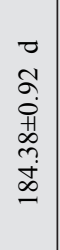 & 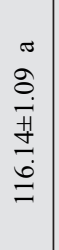 & $\begin{array}{l}0 \\
\hat{\sigma} \\
0 \\
0+1 \\
0 \\
\dot{0} \\
\dot{0} \\
\dot{0}\end{array}$ & 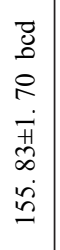 & 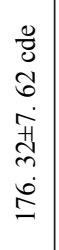 & $\begin{array}{l}\vec{n} \\
\dot{0} \\
a \\
\dot{n} \\
\dot{m}\end{array}$ & $\begin{array}{l}\infty \\
\infty \\
i \\
+0 \\
0 \\
0 \\
\dot{n} \\
2\end{array}$ & \begin{tabular}{l|}
0 \\
0 \\
+ \\
$\dot{+}$ \\
$\dot{+}$ \\
$\dot{0}$ \\
$\dot{\vec{m}}$ \\
\end{tabular} & 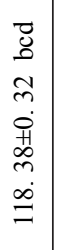 & 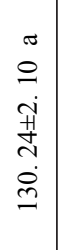 & $\sigma^{\pi}$ & 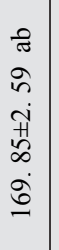 & 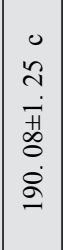 \\
\hline & 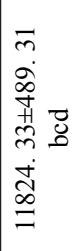 & $\begin{array}{l}\tilde{c} \\
\tilde{b} \\
\tilde{n} \\
\tilde{n} \\
\tilde{N} \\
\tilde{n} \\
\infty \\
\infty \\
\tilde{n} \\
\tilde{m}\end{array}$ & 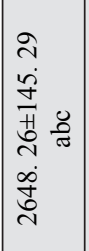 & 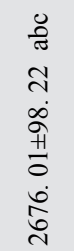 & $\begin{array}{l}\overrightarrow{0} \\
\vec{\infty} \\
0 \\
0 \\
0 \\
0 \\
0 \\
=\end{array}$ & 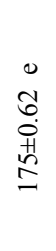 & $\begin{array}{l}0 \\
n \\
0 \\
0 \\
0 \\
0 \\
0 \\
\vdots \\
\vdots \\
=\end{array}$ & 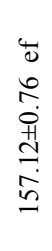 & 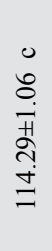 & 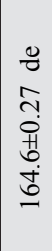 & $\begin{array}{l}\text { बै } \\
\stackrel{0}{0} \\
0 \\
0 \\
0 \\
0\end{array}$ & 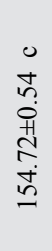 & 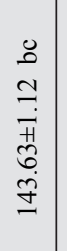 & $\begin{array}{l}0 \\
0 \\
9 \\
0 \\
0 \\
\pm 1 \\
0 \\
0 \\
\dot{0} \\
\end{array}$ & 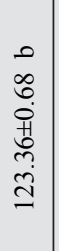 & 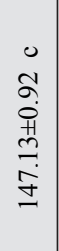 & 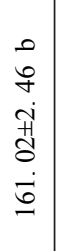 & 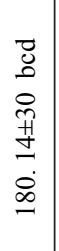 & 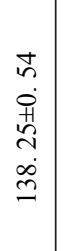 & 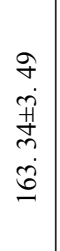 & 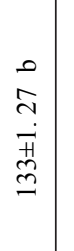 & 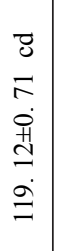 & 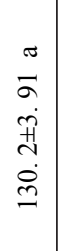 & 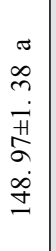 & 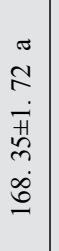 & 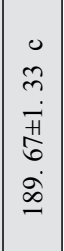 \\
\hline & 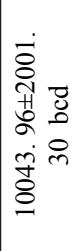 & 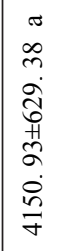 & 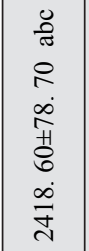 & 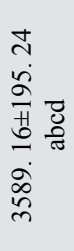 & 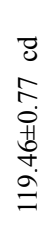 & 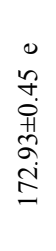 & 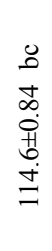 & 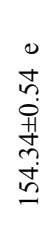 & $\begin{array}{l}0 \\
= \\
= \\
+ \\
6 \\
6 \\
0 \\
0\end{array}$ & 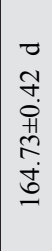 & 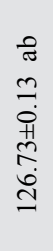 & $\begin{array}{l}0 \\
8 \\
0 \\
\dot{0} \\
\ddot{1} \\
0 \\
0 \\
0 \\
n\end{array}$ & 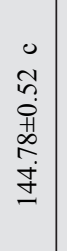 & $\begin{array}{l}0 \\
\infty \\
0 \\
0 \\
+1 \\
\stackrel{0}{0} \\
\dot{0} \\
0\end{array}$ & 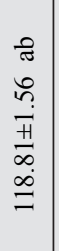 & 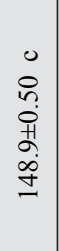 & 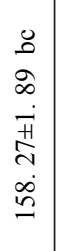 & 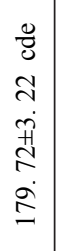 & 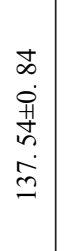 & $\begin{array}{l}\infty \\
n \\
n \\
\ddot{n} \\
\alpha \\
\infty \\
\infty \\
n\end{array}$ & 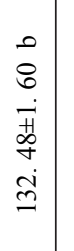 & 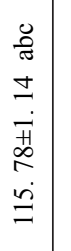 & 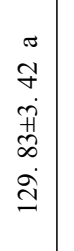 & 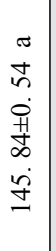 & $\begin{array}{l}0 \\
\tilde{\sigma} \\
2 \\
0 \\
\dot{+1} \\
\dot{i} \\
\underline{I}\end{array}$ & $\begin{array}{l}0 \\
\tilde{n} \\
\dot{H} \\
\stackrel{+}{+} \\
\dot{a} \\
\dot{a}\end{array}$ \\
\hline & 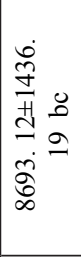 & 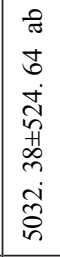 & 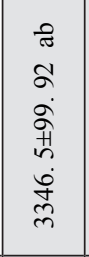 & 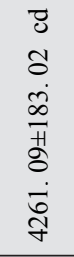 & 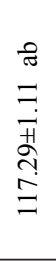 & $\begin{array}{c}0 \\
0 \\
0 \\
0 \\
0 \\
\infty \\
\infty \\
\vdots \\
\\
-\end{array}$ & 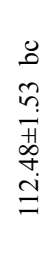 & 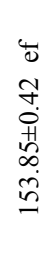 & $\begin{array}{l}0 \\
\infty \\
0 \\
0 \\
01 \\
\propto \\
0 \\
0 \\
0\end{array}$ & $\begin{array}{l}0 \\
0 \\
f \\
0 \\
0 \\
+ \\
0 \\
0 \\
0\end{array}$ & $\begin{array}{l}\text { तै } \\
\text { ते } \\
\text { ஸे } \\
\text { \#1 }\end{array}$ & 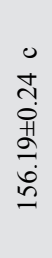 & 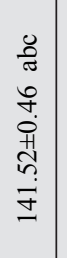 & 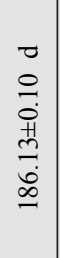 & 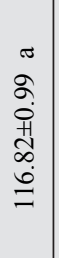 & $\begin{array}{l}0 \\
0 \\
0 \\
0 \\
0 \\
2 \\
0 \\
\infty \\
\dot{0} \\
\end{array}$ & 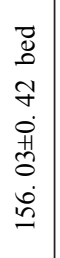 & 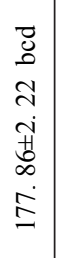 & $\begin{array}{l}\tilde{m} \\
\dot{0} \\
\dot{+} \\
0 \\
\dot{0} \\
\dot{m}\end{array}$ & 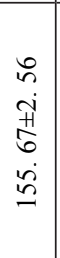 & 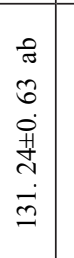 & $\begin{array}{l}\overrightarrow{8} \\
\overrightarrow{+} \\
\dot{\theta} \\
\dot{+} \\
\dot{8}\end{array}$ & 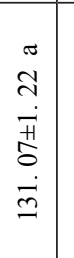 & 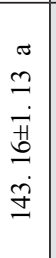 & 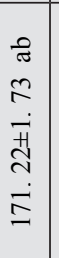 & 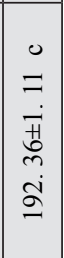 \\
\hline 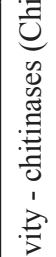 & 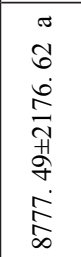 & 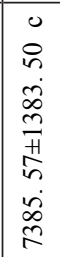 & 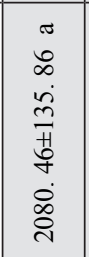 & 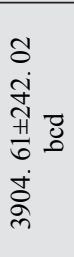 & $\begin{array}{l}0 \\
0 \\
0 \\
0 \\
0 \\
0 \\
\infty \\
0 \\
0 \\
=\end{array}$ & 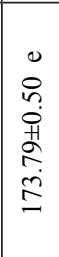 & $\begin{array}{l}\sigma \\
0 \\
0 \\
0 \\
0 \\
\infty \\
0 \\
ٍ \\
=\end{array}$ & 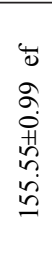 & $\begin{array}{l}\sigma \\
\infty \\
\infty \\
0 \\
0 \\
0 \\
0 \\
\infty \\
\alpha\end{array}$ & $\begin{array}{l}0 \\
0 \\
0 \\
+ \\
0 \\
+1 \\
0 \\
0 \\
\dot{n}\end{array}$ & 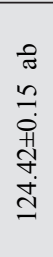 & $\begin{array}{l}0 \\
0 \\
0 \\
0 \\
0 \\
0 \\
0 \\
0 \\
0\end{array}$ & 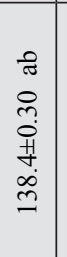 & $\begin{array}{l}0 \\
\infty \\
\infty \\
\tilde{0} \\
+1 \\
0 \\
\infty \\
\infty \\
-\end{array}$ & 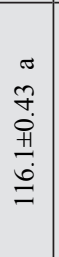 & 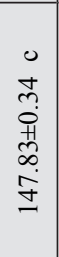 & 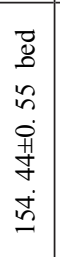 & 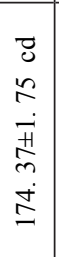 & $\begin{array}{l}\text { I } \\
0 \\
0 \\
0 \\
\infty \\
\infty \\
0\end{array}$ & 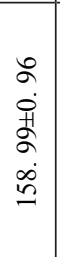 & 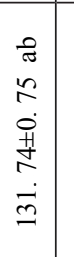 & 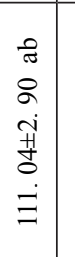 & $\begin{array}{l}\tilde{0} \\
\stackrel{8}{0} \\
\dot{0} \\
\stackrel{1}{1} \\
\tilde{m} \\
\dot{0}\end{array}$ & 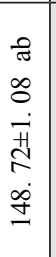 & 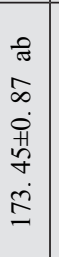 & 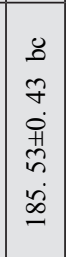 \\
\hline ๘ & 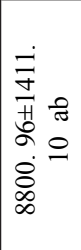 & $\begin{array}{l}0 \\
a \\
\dot{d} \\
\dot{d} \\
\infty \\
\vec{H} \\
\dot{a} \\
\vec{a} \\
\dot{b}\end{array}$ & 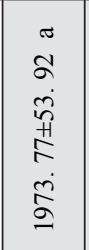 & 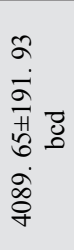 & 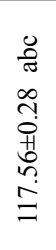 & $\begin{array}{l}0 \\
n \\
\tilde{n} \\
0 \\
+1 \\
0 \\
\dot{I} \\
\text { I }\end{array}$ & 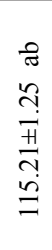 & $\begin{array}{l}4 \\
\text { aे } \\
0 \\
0 \\
\text { t. } \\
\dot{n} \\
\text { an }\end{array}$ & $\begin{array}{l}\sigma \\
0 \\
0 \\
0 \\
0 \\
\tilde{0} \\
\hat{\alpha} \\
\alpha\end{array}$ & $\begin{array}{l}0 \\
0 \\
F \\
0 \\
0 \\
0 \\
0 \\
0\end{array}$ & 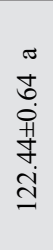 & $\begin{array}{l}0 \\
\vec{n} \\
0 \\
01 \\
0 \\
\text { in } \\
\text { in }\end{array}$ & 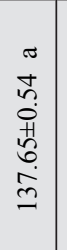 & 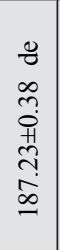 & 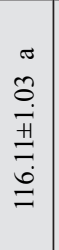 & 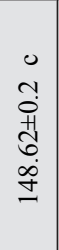 & 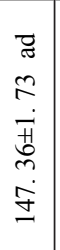 & 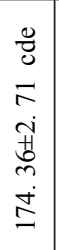 & 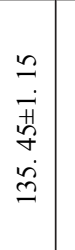 & $\begin{array}{l}\infty \\
\infty \\
i \\
\vec{H} \\
0 \\
\dot{0} \\
\qquad \\
\end{array}$ & 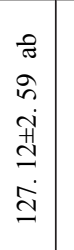 & 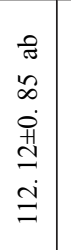 & 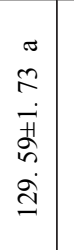 & $\begin{array}{l}0 \\
\infty \\
0 \\
0 \\
0 \\
\infty\end{array}$ & 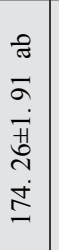 & $\begin{array}{l}+ \\
+ \\
\dot{D}\end{array}$ \\
\hline & 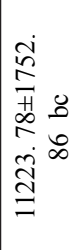 & 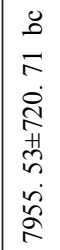 & 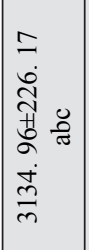 & 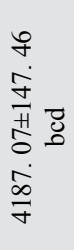 & 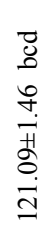 & 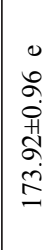 & 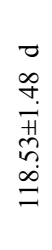 & 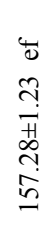 & חֶ. & 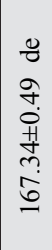 & 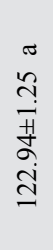 & 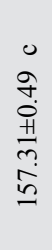 & 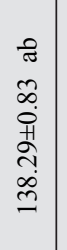 & 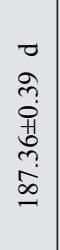 & 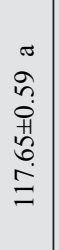 & $\begin{array}{l}0 \\
\infty \\
0 \\
0 \\
0 \\
6 \\
0 \\
0 \\
\dot{0} \\
\end{array}$ & $\begin{array}{l}\overrightarrow{0} \\
2 \\
\partial \\
\dot{\vec{H}} \\
\dot{\alpha} \\
\dot{\sigma} \\
\dot{g}\end{array}$ & 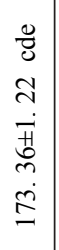 & $\begin{array}{l}\overrightarrow{0} \\
\overrightarrow{\dot{H}} \\
\dot{\vec{\Xi}} \\
\end{array}$ & $\begin{array}{l}8 \\
\dot{0} \\
i \\
+ \\
i \\
i \\
\infty \\
0 \\
0\end{array}$ & 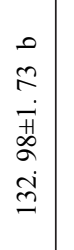 & 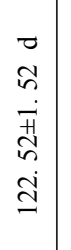 & 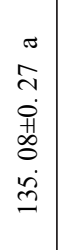 & 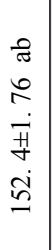 & 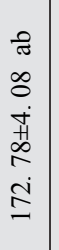 & 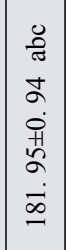 \\
\hline & 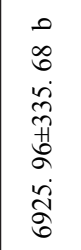 & 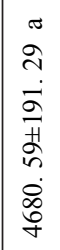 & 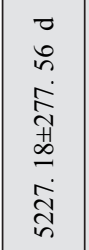 & 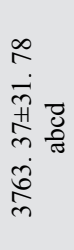 & 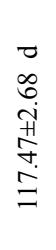 & 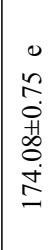 & 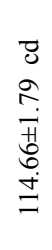 & 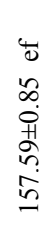 & 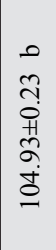 & $\begin{array}{l}0 \\
\text { aे } \\
0 \\
0 \\
0\end{array}$ & $\begin{array}{l}\text { f } \\
\text { i } \\
\text { d }\end{array}$ & 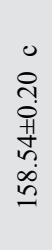 & 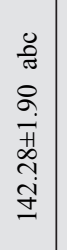 & $\begin{array}{l}0 \\
\hat{0} \\
0 \\
0 \\
0 \\
\infty \\
\infty \\
\infty \\
-\end{array}$ & 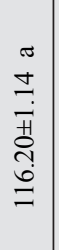 & 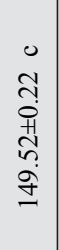 & 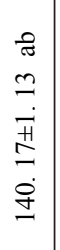 & $\begin{array}{l}0 \\
0 \\
0 \\
\infty \\
0 \\
01 \\
0 \\
0 \\
\dot{0}\end{array}$ & $\begin{array}{l}0 \\
+ \\
i \\
i \\
\infty \\
\infty \\
\infty \\
\infty \\
0\end{array}$ & 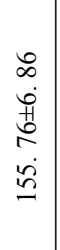 & 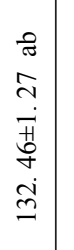 & $\begin{array}{l}0 \\
0 \\
o \\
0 \\
0 \\
0 \\
0 \\
\infty \\
\infty \\
=\end{array}$ & 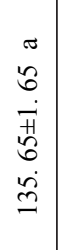 & $\begin{array}{l}\tilde{\sigma} \\
\tilde{0}\end{array}$ & 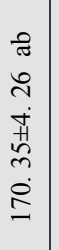 & $\begin{array}{l}7 \\
0 \\
0 \\
0 \\
0 \\
\infty \\
\infty\end{array}$ \\
\hline & $\stackrel{n}{<}$ & $\begin{array}{l}n \\
+ \\
+\end{array}$ & $\sum_{1}^{n}$ & $\begin{array}{l}y \\
x \\
+\end{array}$ & $\sum_{1}^{2}$ & & $<$ & & & & \& & $\begin{array}{l}\text { 量 } \\
+\end{array}$ & $\begin{array}{l}\sum_{1}^{2} \\
1\end{array}$ & $\begin{array}{l}y \\
\dot{z} \\
+\end{array}$ & 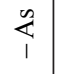 & $\begin{array}{l}n \\
+ \\
+\end{array}$ & $\sum_{1}^{n}$ & $\begin{array}{l}\sum_{4}^{n} \\
+\end{array}$ & $\sum_{1}^{\infty}$ & $\begin{array}{l}n \\
+ \\
+\end{array}$ & $\sum_{1}^{n}$ & $\begin{array}{l}\sum_{+}^{n} \\
+\end{array}$ & $\sum_{1}^{2}$ & + & $\stackrel{2}{4}_{1}^{0}$ & + \\
\hline & $\approx$ & $\simeq$ & ns & n & $\simeq$ & $\simeq$ & 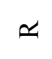 & $\simeq$ & . & & & $\Omega$ & $n$ & $n$ & is & $\infty$ & $\simeq$ & $\simeq$ & $\simeq$ & $\simeq$ & $\simeq$ & $\simeq$ & $\simeq$ & $\approx$ & is & $n$ \\
\hline & \multicolumn{2}{|c|}{ 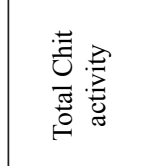 } & \multicolumn{2}{|c|}{ 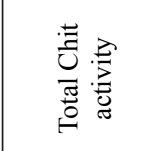 } & \multicolumn{2}{|c|}{ 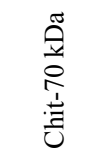 } & \multicolumn{2}{|c|}{ 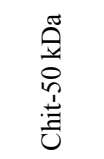 } & \multicolumn{2}{|c|}{ 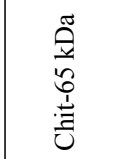 } & \multicolumn{2}{|c|}{ 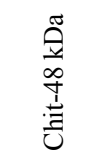 } & \multicolumn{2}{|c|}{ 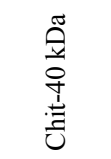 } & \multicolumn{2}{|c|}{ 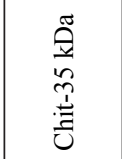 } & \multicolumn{2}{|c|}{ 芯 } & \multicolumn{2}{|c|}{ 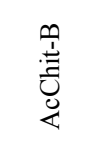 } & \multicolumn{2}{|c|}{ 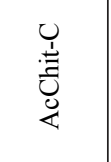 } & \multicolumn{2}{|c|}{ 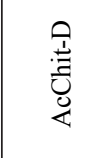 } & \multicolumn{2}{|c|}{ 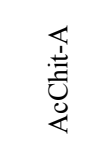 } \\
\hline
\end{tabular}




\begin{tabular}{|c|c|c|c|c|c|c|c|c|c|c|c|c|c|c|c|c|}
\hline $\begin{array}{l}\sigma \\
\pm \\
\dot{J} \\
\dot{H} \\
\infty \\
\dot{0} \\
\dot{0}\end{array}$ & \begin{tabular}{|c|}
0 \\
0 \\
0 \\
0 \\
0 \\
$\dot{1}$ \\
0 \\
$\infty$ \\
$\infty$ \\
$\infty$ \\
\hdashline
\end{tabular} & 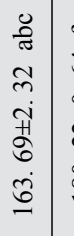 & 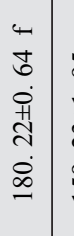 & $\begin{array}{l}0 \\
n \\
\dot{\vec{H}} \\
\hat{n} \\
\vdots \\
\vdots\end{array}$ & 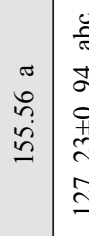 & 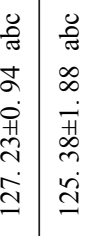 & 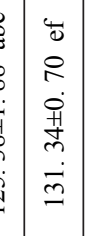 & 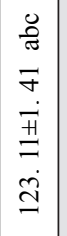 & $\begin{array}{l}n \\
\sim \\
\overrightarrow{1} \\
\sim \\
\infty \\
\dot{\vec{m}} \\
\dot{m}\end{array}$ & 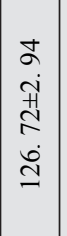 & $\begin{array}{c}n \\
n \\
i \\
y \\
d \\
\infty \\
\alpha \\
\alpha\end{array}$ & $\begin{array}{c}q \\
o \\
i \\
y \\
d \\
g \\
g\end{array}$ & 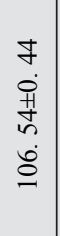 & $\begin{array}{l} \pm \\
\dot{J} \\
\dot{0} \\
\stackrel{+}{1} \\
\stackrel{\dot{0}}{0}\end{array}$ & 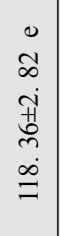 & 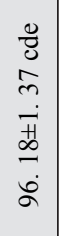 \\
\hline 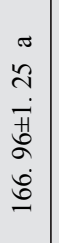 & \begin{tabular}{|c|}
0 \\
0 \\
0 \\
0 \\
0 \\
0 \\
0 \\
$\dot{0}$ \\
$\infty$ \\
$-\infty$
\end{tabular} & 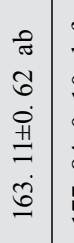 & 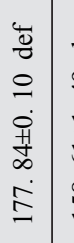 & 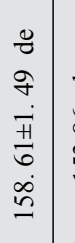 & 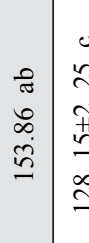 & 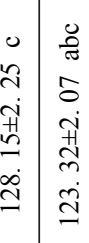 & 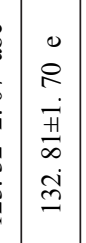 & 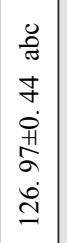 & $\begin{array}{c}\infty \\
\infty \\
\vec{H} \\
0 \\
\dot{\vec{m}} \\
\dot{m}\end{array}$ & 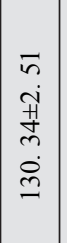 & $\begin{array}{l}\tilde{m} \\
\tilde{H} \\
\tilde{m} \\
\alpha \\
\delta \\
\delta\end{array}$ & 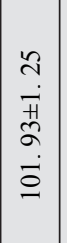 & $\begin{array}{l}\tilde{m} \\
\stackrel{\vec{H}}{*} \\
\dot{H} \\
\dot{0} \\
\dot{0}\end{array}$ & 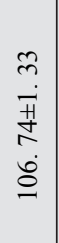 & 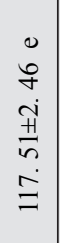 & $\begin{array}{l}z \\
\tilde{J} \\
q \\
i \\
i \\
\infty \\
\infty \\
\sigma \\
\sigma\end{array}$ \\
\hline
\end{tabular}

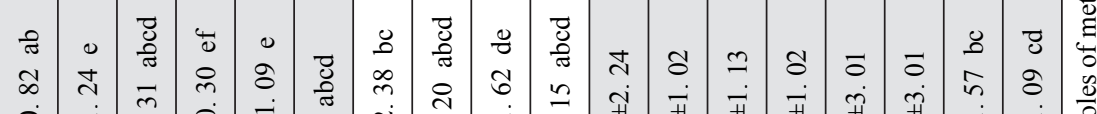

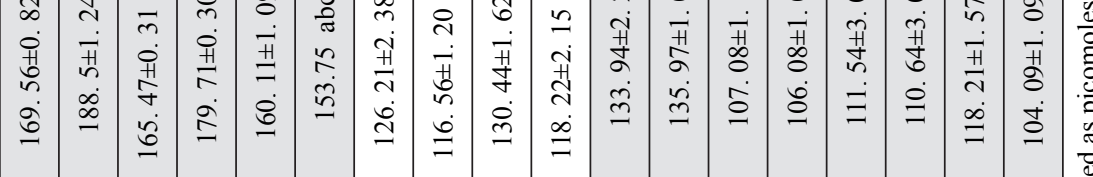

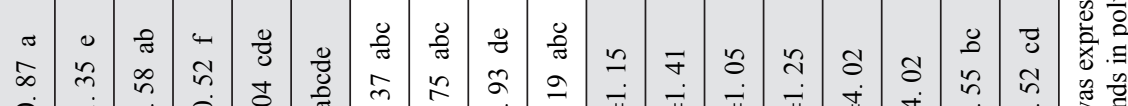

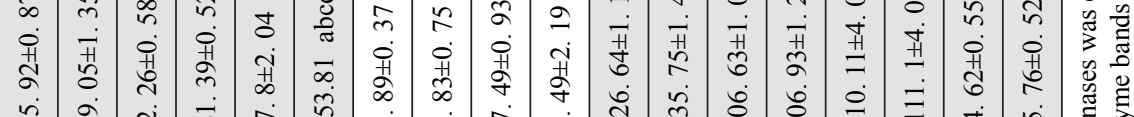

ம்

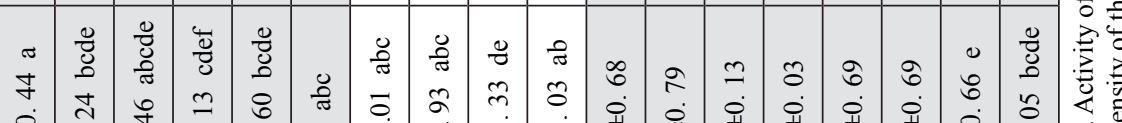

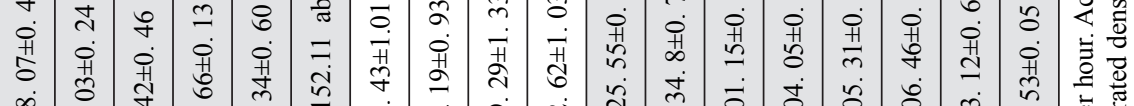

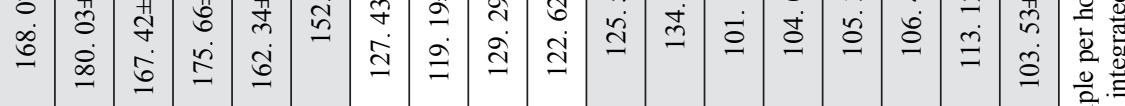

$\approx$ व

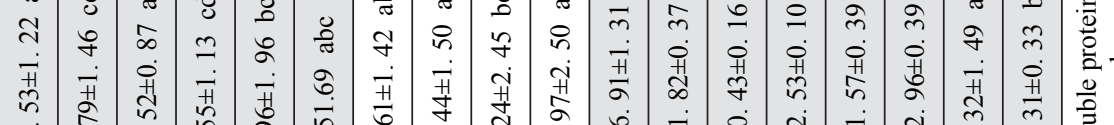

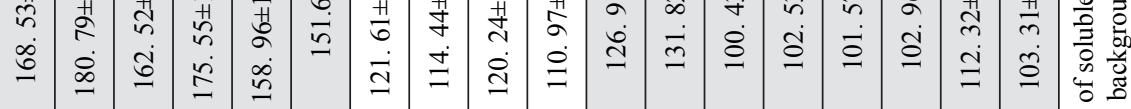

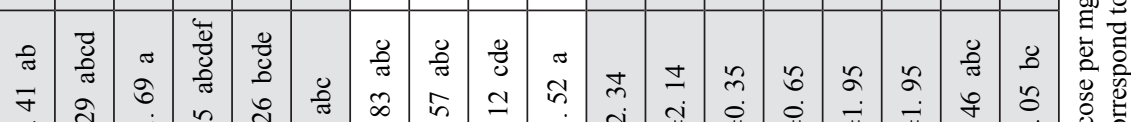

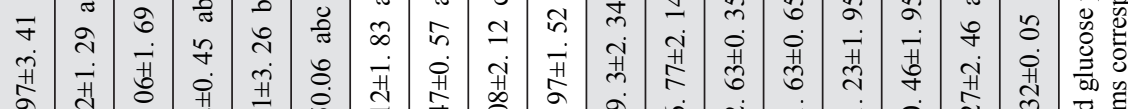

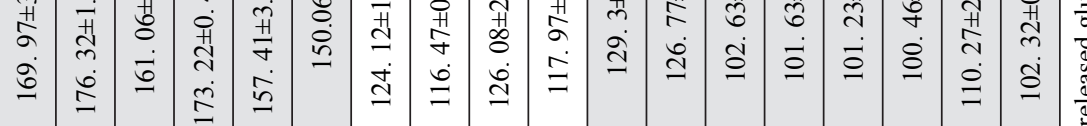

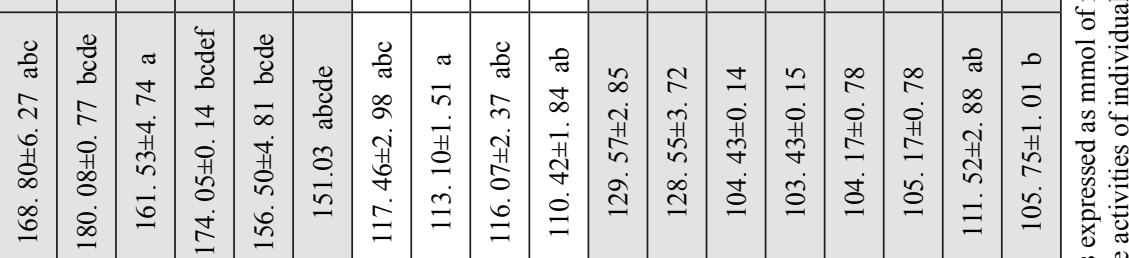

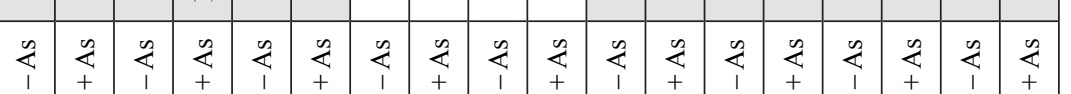

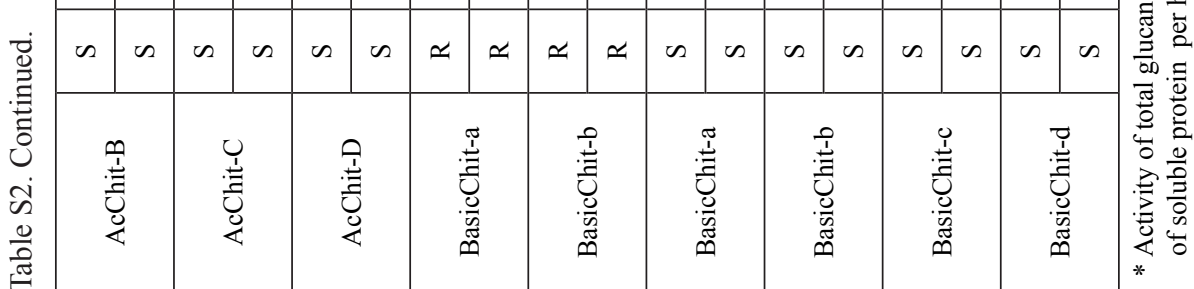

